\title{
Mineralogy, Fluid Inclusion, and C-O-Sr Isotope Geochemistry to Unravel the Evolution of the Magmatic-Hydrothermal System at the Igoudrane Silver-Rich Deposit (Imiter District, Eastern Anti-Atlas, Morocco)
}

\author{
Mamadoudjan Diallo ${ }^{1, *}$, Mohammed Bouabdellah ${ }^{1, *}$, Gilles Levresse ${ }^{2}$, Johan Yans ${ }^{3}$ (D), Francesca Castorina ${ }^{4,5}$, \\ Andreas Klügel ${ }^{6}$, Mohamed Mouhagir ${ }^{7}$, Salim El Mouden ${ }^{7}$ and Lhou Maacha ${ }^{7}$
}

1 Laboratoire des Gîtes Minéraux, Hydrogéologie \& Environnement, Faculté des Sciences, Oujda 60000, Morocco

2 Programa de Geofluidos, Centro de Geociencias UNAM-Campus Juriquilla, AP 1-253, Querétaro Mexico CP 76230, Mexico; glevresse@gmail.com

3 Institute of Life-Earth-Environment (ILEE), University of Namur, 61 rue de Bruxelles, B-5000 Namur, Belgium; johan.yans@unamur.be

4 Dipartimento di Scienze della Terra, Università "La Sapienza”, P.le Aldo Moro, 00185 Rome, Italy; francesca.castorina@uniroma1.it

check for updates

Citation: Diallo, M.; Bouabdellah, M.; Levresse, G.; Yans, J.; Castorina, F.; Klügel, A.; Mouhagir, M.; El Mouden, S.; Maacha, L. Mineralogy, Fluid Inclusion, and C-O-Sr Isotope Geochemistry to Unravel the Evolution of the

Magmatic-Hydrothermal System at the Igoudrane Silver-Rich Deposit (Imiter District, Eastern Anti-Atlas, Morocco). Minerals 2021, 11, 997. https://doi.org/10.3390/ $\min 11090997$

Academic Editor: Joel E. Gagnon

Received: 21 August 2021

Accepted: 8 September 2021

Published: 12 September 2021

Publisher's Note: MDPI stays neutral with regard to jurisdictional claims in published maps and institutional affiliations.

Copyright: (c) 2021 by the authors. Licensee MDPI, Basel, Switzerland. This article is an open access article distributed under the terms and conditions of the Creative Commons Attribution (CC BY) license (https:/ / creativecommons.org/licenses/by/ $4.0 /)$.
5 Istituto di Geologia Ambientale e Geoingegneria del CNR, Sezione di Roma “La Sapienza”, 00185 Rome, Italy

6 Fachbereich Geowissenschaften, Universität Bremen, Postfach 33 04 40, 28334 Bremen, Germany; akluegel@uni-bremen.de

7 Managem Group, Twin Center, Tour A, Angle Boulevard Zerktouni et Al Massira Al Khadra, B.P. 5199, Casablanca 20000, Morocco; m.mouhajir@managemgroup.com (M.M.);

s.elmouden@managemgroup.com (S.E.M.); L.MAACHA@MANAGEMGROUP.COM (L.M.)

* Correspondence: diallo_mamadoudjan@yahoo.fr (M.D.); mbouabdellah2002@yahoo.fr (M.B.)

\begin{abstract}
The Igoudrane mine with a total production of 700,000 $\mathrm{t}$ of ore grading $485 \mathrm{~g} / \mathrm{t} \mathrm{Ag}$ is currently one of the most productive mines in the Imiter district of the eastern Anti-Atlas in Morocco. The silver-rich \pm base metal deposit occurs dominantly as vein- and hydrothermal breccia-hosted orebodies at the interface between the lower Ediacaran turbidites of the Saghro Group and the unconformably overlying, dominantly felsic volcanic, and volcaniclastic rocks of the late Ediacaran Ouarzazate Group. Higher-grade ores are lithologically hosted by the uppermost organic-rich black shale unit and structurally controlled by the intersection of subvertical NW- and NE-trending fault systems. Ore-related hydrothermal alteration includes, in order of decreasing abundance, carbonatization, silicification, sericitization, and chloritization. Three primary paragenetic stages of veining and associated silver \pm base metal mineralization have been recognized: (1) early pyrite + quartz + Ag-bearing sulfides and sulfosalts; (2) main Ag-bearing sulfides and sulfosalts + calcite \pm fluorite \pm dolomite; and (3) late quartz + calcite + base-metal sulfides (galena, sphalerite, pyrite, chalcopyrite). Irrespective of the ore stage, the dominant Ag-bearing ore minerals are $\mathrm{Ag}-\mathrm{Hg}$ amalgam, argentite, freibergite, acanthite, polybasite, pyrargyrite, and proustite. Fluid inclusion data show a trend of decreasing temperatures with time, from the main silver stage $\left(\mathrm{T}_{\mathrm{h}}=180 \pm 12{ }^{\circ} \mathrm{C}\right)$ to late base-metal stage $\left(\mathrm{T}_{\mathrm{h}}=146 \pm 7^{\circ} \mathrm{C}\right)$, consistent with fluid mixing, cooling, and/or dilution. The coexistence of aqueous-rich and vapor-rich fluid inclusions together with variations in bulk salinity $\left(\mathrm{NaCl}+\mathrm{CaCl}_{2}\right)$ of the mineralizing fluids during the main silver stage, at similar temperatures, indicate that boiling and subsequent degassing occurred during the main ore-forming event due to a pressure decrease. Calculated $\delta^{18} \mathrm{O}_{\text {fluid }}$ values along with $\mathrm{REE}+\mathrm{Y}$ and $\mathrm{Sr}$ isotope constraints suggest that the ore-forming fluids originated from a predominantly magmatic source, although incursion of meteoric waters during collapse of the hydrothermal system could have contributed to deposition. The post-ore, base-metal quartz-carbonate-dominated mineralization was deposited from dilute Ca-Na-Cl-bearing fluids at temperature below $150^{\circ} \mathrm{C}$. Overall, fluid-rock interaction with the black shales along major faults and thin permeable horizons, boiling-degassing-with subsequent fluid mixing, cooling, and/or dilution-were the main mechanisms of silver deposition.
\end{abstract}


Keywords: Igoudrane silver-rich deposit; fluid inclusion; C-O-Sr isotope geochemistry; boilingcooling-fluid mixing; Anti-Atlas (Morocco)

\section{Introduction}

The world-class Imiter district of the Moroccan Anti-Atlas system consists of six closely distributed silver-rich mines referred to, from west to east, as Imiter 1, Imiter 2, Imiter Sud, B8 structure, Puits IV, and Igoudrane (Figure 1A,B); all of which are currently exploited and explored by Managem Group. Reported total silver resources from all deposits including those mined out from 1970 to 2018 exceeded $11 \mathrm{Mt}$ at an average grade of $521 \mathrm{~g} / \mathrm{t} \mathrm{Ag}$. Although significant progress has been made on the origin of these deposits, critical factors that control their genesis are still not clearly constrained. The disagreement regarding the age of mineralization has created controversy over the sources of ore-forming fluids and metals, and both magmatic-epithermal model at $550 \pm 3$ Ma coincident with the emplacement of Neoproterozoic felsic intrusions [1-4] and deep circulation of basinal brines related to the opening of the Atlantic Ocean during the Permian-Triassic times [5] have been proposed. The resolution of this controversy is crucial because the two proposed models place Imiter orebodies in very different geologic settings that lead to contrasting global exploration strategies.

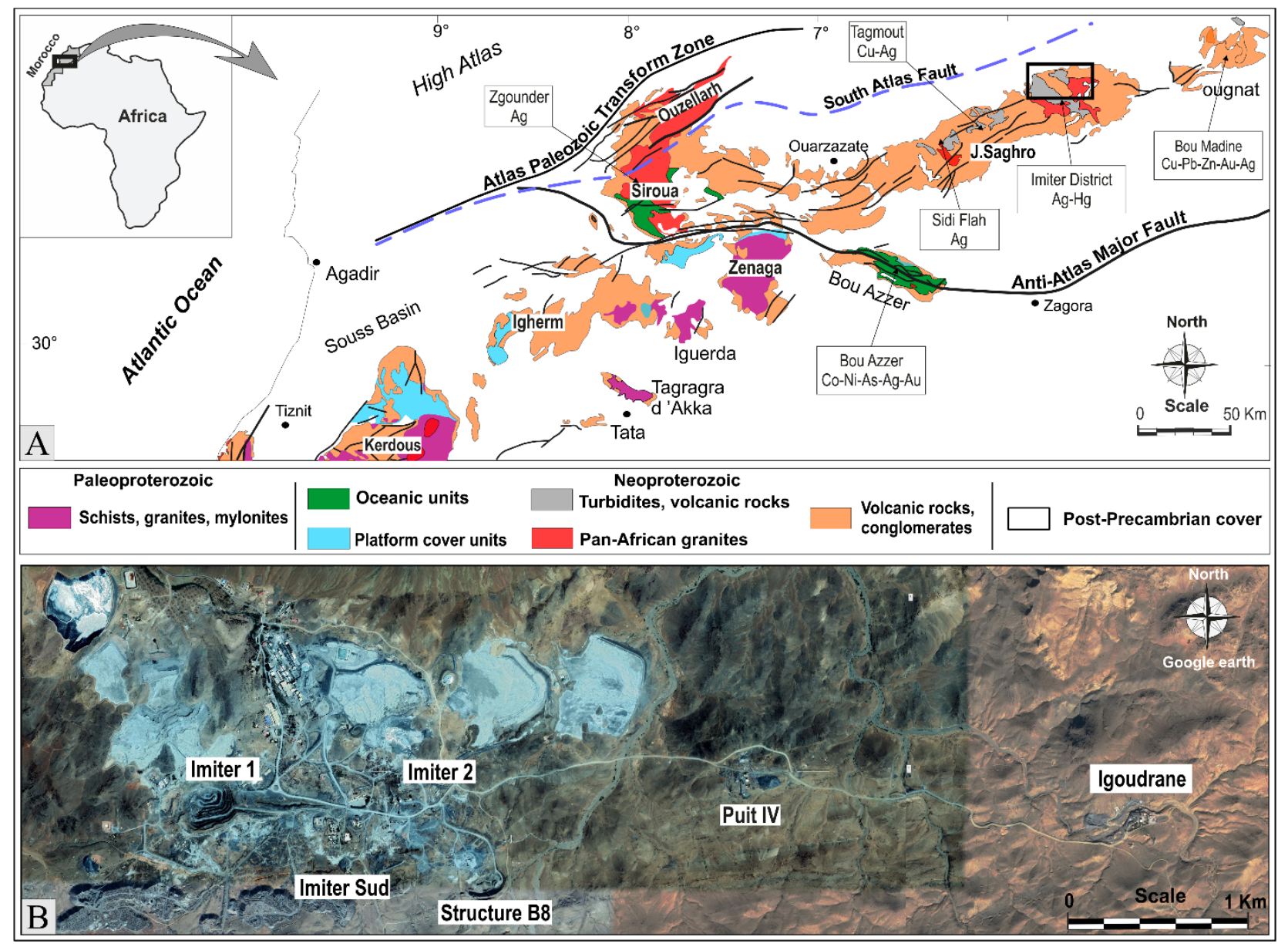

Figure 1. (A) Structural map of Anti-Atlas orogen displaying the main Precambrian inliers and spatial distribution of main historically mined polymetallic districts, projected to surface (adapted from [6,7]). The inset shows the location of the Anti-Atlas belt within the framework of Morocco and Africa continent. (B) Google Earth picture showing the spatial distribution of the six principal mines that form the world-class silver-rich Imiter district. 
Recent exploration activities in the Imiter district delineated, in its easternmost part, the Igoudrane deposit as a significant mine site where ore-grade silver mineralization has been intersected to a depth of $\sim 670 \mathrm{~m}$. This deposit shares many common features with other deposits of the district in term of geological environment (i.e., type and age of the host rocks), tectonic setting, magmatic association, mineralization styles, wall-rock alteration, ore mineralogy, metal composition, and silver grades. However, its mineralogy is unique in that the gangue minerals are dominated by calcite and fluorite instead of dolomite and quartz, and the exploited mineralized structures as a large part of the Imiter vein system are hosted in NW- to E-W-trending north-dipping structures rather than the dominant NE-SWoriented south-dipping veins that commonly characterize the other deposits of the district. More importantly, the Igoudrane deposit is the only mine site of the district where Ag- $\mathrm{Hg}$ mineralization is juxtaposed with, or adjacent to, the apices of an exposed granitic intrusion referred to as the Igoudrane intrusion. Such a relationship revives the debates on whether this association is spatial or genetic, as the Igoudrane intrusion correlates very closely with the distribution of Ag-Hg mineralization. Between 2006, when production started from underground workings and 2018, the Igoudrane mine has produced 680,000 tons of ore averaging $485 \mathrm{~g} / \mathrm{t} \mathrm{Ag} \mathrm{making} \mathrm{it} \mathrm{one} \mathrm{of} \mathrm{the} \mathrm{world's} \mathrm{largest} \mathrm{and} \mathrm{richest} \mathrm{silver} \mathrm{ore} \mathrm{deposits.}$

To date, no detailed mineralogic, fluid inclusion, or isotopic geochemical investigations have been performed on this deposit, except for a few reconnaissance surveys carried out during exploration and mine planning. The study of the Igoudrane deposit could therefore provide key information on the long-standing controversy on the origin of the Imiter silverrich mineralization. In this contribution, we present the first field and laboratory-based geologic features, type, and composition of ore and alteration minerals, mineral chemistry, fluid inclusion microthermometry, and stable $(\mathrm{C}, \mathrm{O})$ and radiogenic $(\mathrm{Sr})$ isotope data on the hydrothermal assemblages for the Igoudrane Ag-rich $\pm \mathrm{Pb}$ - $\mathrm{Zn}$ deposit. These integrated data are used to: (1) document the petrography and geochemistry of the spatially associated igneous rocks, hydrothermal alteration, styles of mineralization, and vein paragenesis; (2) decipher the origin, fluid composition and physicochemical conditions of the oreforming fluids that led to deposition of silver-rich mineralization; and (3) constrain metal source(s) and controls on ore deposition.

\section{Regional Geological Setting}

The field area for the current study is located within the Saghro massif of the PanAfrican Anti-Atlas orogen, and defines the easternmost end of the Imiter high-grade silver district (Figures 1 and 2). The oldest rocks are assigned to the supracrustal turbiditic series of the Saghro Group, which are unconformably overlain by the sub-horizontal volcanic (dominantly felsic) and clastic formations of the Late Ediacaran Ouarzazate Group (ca. 570-540 Ma) [7-10]. All these supracrustal rocks have undergone hydrothermal alteration and greenschist facies metamorphism, which contrasts with the higher metamorphic grades that occur nearby the igneous intrusions. Lithostratigraphically, the Saghro Group consists of up to $8000 \mathrm{~m}$-thick of flysch-like turbiditic sequences that comprise alternating successions of fine-grained, laminated sandy (silts, greywackes, arkoses) and pelitic (greywackes, organic-rich pelites, and metabasites) units that accumulated in a back-arc setting marginal to West Africa in a time window of ca. 604 to $630 \mathrm{Ma}[11,12]$. Recent U-Pb age determinations indicate a maximum depositional age of $610 \mathrm{Ma}$ (TIMS and SHRIMP U-Pb on zircons [7,13,14]), whereas Errami [12] who proposed an Early Ediacaran age of $604 \pm 5 \mathrm{Ma}$ as the new maximum depositional age for the Saghro Group series. Back-arc basin closure which was caused by a collision with the Precambrian basement of the Atlas-Meseta domain occurred in a transpressional regime at the latest between $600 \pm 3 \mathrm{Ma}$ and $607 \pm 6 \mathrm{Ma}$ [12]. This time span records the latest compressional and/or transpressional, synmetamorphic event of the Pan-African orogenic cycle in the Anti-Atlas, therefore leaving the way for the onset of the Cadomian Orogeny at ca. 570 Ma onwards [11,12,15,16]. 


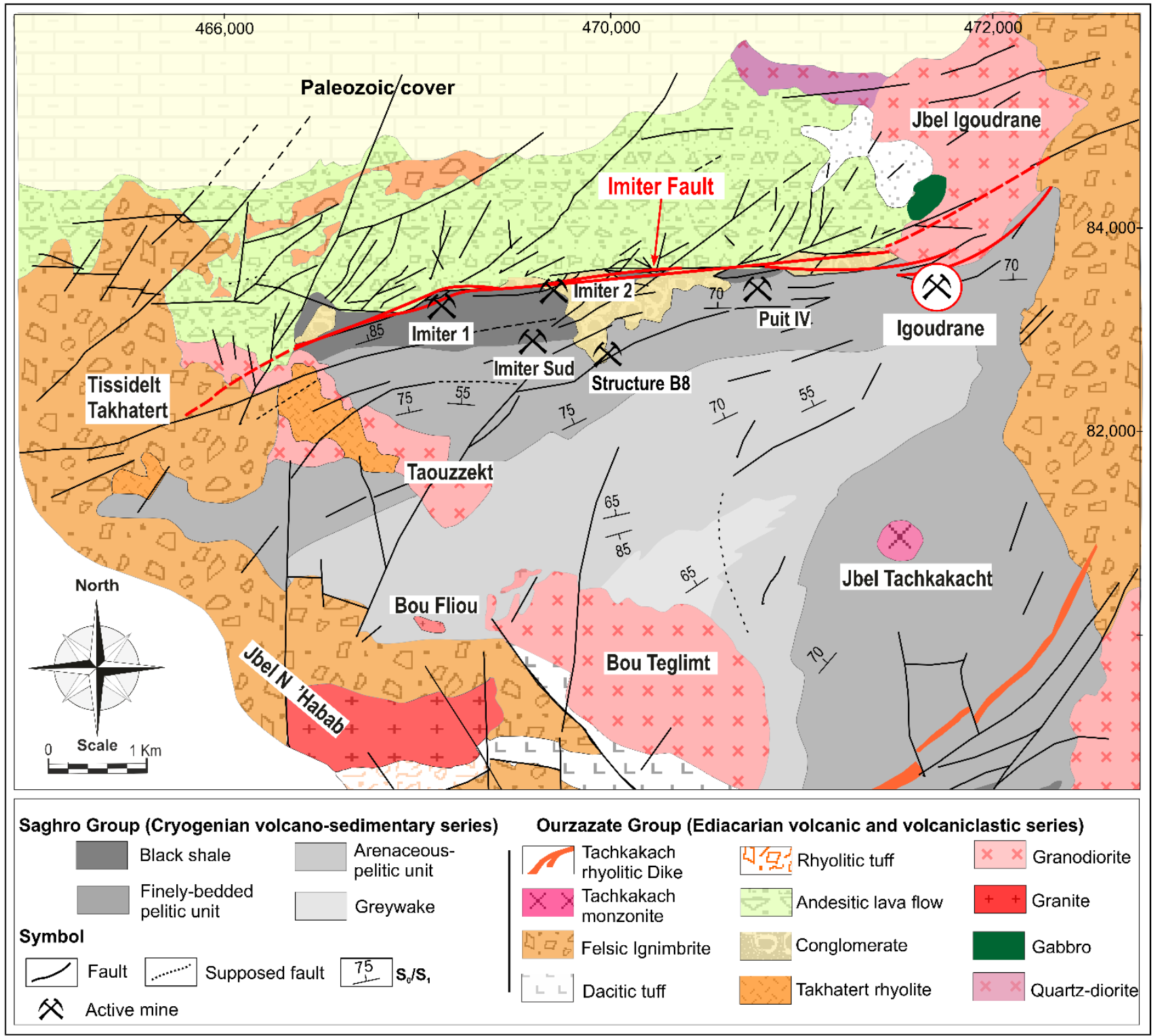

Figure 2. District-scale surface geologic setting of the Imiter silver-rich district including the studied Igoudrane deposit illustrating the distribution of main lithologic units, the extent of structural styles, and their relationship to the Neoproterozoic and post-Neoproterozoic igneous and pyroclastic rocks. The map also shows the locations of the currently exploited mines (projected to surface).

Unconformably overlying the turbiditic series of the Saghro Group are the folded and low-grade volcanic and volcaniclastic formations of the Late Ediacaran Ouarzazate Group, the conformably overlying Lower Cambrian sandstones, and younger, mostly sedimentary, Paleozoic sequences. The Late Ediacaran post-orogenic Ouarzazate Group, the base of which has been dated at 575-565 Ma [10,12], comprises a package of up to $2000 \mathrm{~m}$-thick succession of undeformed subaerial molasse deposits, ignimbritic and rhyolitic lava flows, and domes with associated trachy-andesites, tuffs, and conglomerates. These have been intruded by a set of post-collisional medium- to high-K calc-alkaline to alkaline, and shoshonitic granitoids and localized ultramafic stocks, and subvolcanic dike swarms [8,17]. These rocks, which deposited in extensional ENE-WSW [18-20] to $\mathrm{E}-\mathrm{W}[2,8,21,22]$ controlled continental basins under terrestrial conditions accumulated between ca. 580 to $543 \mathrm{Ma}$ along the northern margin of the WAC $[7,23]$ during the latest Ediacaran to Lower Cambrian time [24-27]. 
Recent TIMS and SHRIMP U-Pb zircon age determinations indicate that the mediumto-high-K calc-alkaline to alkaline magmatism occurred in a post-collisional transtensionextension setting between ca. 615 and $555 \mathrm{Ma}[2,7,8,10,12,13,20,28-30]$; and references therein). Geodynamically, most of the cited petrogenetic models relate the evolution of the Ediacaran high-K calc-alkaline to alkaline magmatic series either to subduction and recycling of the subducted crust during the waning stages of the Pan-African collision (i.e., subduction model; $[10,15,31,32])$ or alternatively to a post-collisional or anorogenic extensional rifting stage related to the onset of the Cadomian orogeny [7,8,33-36].

Paleozoic series ranging in age from Cambrian to Carboniferous thrusted onto the Anti-Atlas during the Late Carboniferous Variscan orogeny at ca. 300 Ma [37-39].

\section{Local Geology Setting}

\subsection{Stratigraphy, Metamorphism, and Structural Geology}

In the mine area, the dominant host rocks, stratigraphically assigned to the Lower Ediacaran Saghro Group [11], consist of a succession of four highly deformed and greenschist facies metamorphosed volcano-sedimentary turbiditic units, including from the bottom to top (Figure 2): (i) a lower sandstone unit; (ii) an intermediate sandstone-pelitic unit; (iii) a pelitic unit; and (iv) an uppermost organic-rich black shale unit with interbedded volcanic and volcaniclastic rocks which constitutes the exclusive host for the silver-rich $\pm \mathrm{Pb}-\mathrm{Zn}$ ores. The host units are intruded and cut by widespread undeformed volcanic, and intrusive rocks of the ca. 570-540 Ma Late Ediacaran Ouarzazate Group [7-10], which in turn are truncated by a doleritic-diabasic dike swarm related to the opening of the central Atlantic at $200 \mathrm{Ma}$ [40]. The unconformably overlying Middle Cambrian carbonate platform to the north of the Igoudrane mine consists predominantly of a succession of limestone and calcareous rocks.

The main structural features of the Igoudrane area are (1) the widespread axial-planar foliation ' $S_{1}$ ', which is attributed to the $D_{1}-D_{2}$ deformation events that coincides with the latest compressional and/or transpressional, synmetamorphic event of the Pan-African orogeny and the onset of the Cadomian events [11]; and (2) the N-S, E-W, NE-SW, and NW-SE fault systems. Of these, the roughly E-W oriented trans-crustal Imiter Fault corridor is of prime relevance as it hosts, or is close to, the major silver-bearing quartz-carbonate mineralized vein structures of the Imiter district. Structural constraints indicate that (1) each of the aforementioned fault systems might have undergone a polyphase motion history; (2) N-S and NW-SE-trending faults were later displaced by the NE-SW to E-W fault systems, with the latter developing pull apart structures by sinistral strike-slip components of motion; and (3) the relative age of the Imiter Fault corridor which shows a major dip-slip component is inferred to be older than $550 \mathrm{Ma}$ [41-43]. Absolute normal displacement, as constrained by offsets of the northern domain, is between 300 and $400 \mathrm{~m}$ [44]. The ductile and/or brittle nature of the host rock predetermined the shape of the mineralized structures. The occurrence of a muscovite-chlorite \pm epidote \pm calcite \pm quartz mineral assemblage provides evidence that the metamorphic conditions attained at least the chlorite zone of the greenschist facies. Development of amphibolite-facies and higher-grade conditions is limited to contact aureole surrounding the margins of uplifted Igoudrane intrusion, which formed at ca. $600{ }^{\circ} \mathrm{C}$ and $\leq 2.3 \mathrm{kbar}$, corresponding to batholith emplacement depths of 8-9 km [11].

\subsection{Igneous and Pyroclastic Rocks}

The exposed volcaniclastic rocks including ignimbrites, tuffs, and volcanic breccias. Their volcano-plutonic counterparts (intrusions, domes, lava flows, subvolcanic bodies, and dikes) are also volumetrically relevant, being well exposed both in outcrops and mine workings (Figure 2). About two-thirds of the igneous and volcaniclastic units are predominantly silicic ( $90 \%$ rhyolite and dacite) being part of the voluminous Ouarzazate Supergroup silicic large igneous province. 


\subsubsection{Intrusive Rocks}

Intrusive rocks which constitute the most abundant lithological units in the Igoudrane area comprise four elongate, NW-SE- to NE-trending, high-K calc-alkaline batholiths referred to as (1) Jbel Igoudrane composite tonalite-granodiorite dated at $565 \pm 5 \mathrm{Ma}$ (U-Pb zircon dating, [28]); (2) Bou Teglimt porphyritic biotite and hornblende-bearing granodiorite dated at $567 \pm 6 \mathrm{Ma}$, (U-Pb zircon dating, [29]); (3) Taouzzekt quartz dioritemonzodiorite dated at $555 \pm 7 \mathrm{Ma}$ (U-Pb zircon dating, [29]), and Jbel Oussikane charnockite dated at $580 \pm 19$ (U-Pb on zircon; [12]) (Figure 2). Of these, the 540-575 $\pm 5 \mathrm{Ma}$ Igoudrane intrusion is of particular interest as it constitutes the only underground visible intrusion in the Imiter district. It can be traced through mining activities to a depth of $600 \mathrm{~m}$ and is juxtaposed with the Ag-Hg orebodies are juxtaposed. The roughly oval-shaped Igoudrane stock intrude with sharp contact the Lower Ediacaran black shales and forms the Igoudrane hill to the north east of the mine. The intrusion is $\sim 2.5 \mathrm{~km}$ long and $0.6-1.4 \mathrm{~km}$ wide (Figure 2) and consist of a gray-, fine-grained quartz-diorite in the eastern contact of the stock, and a predominantly medium-grained hornblende granodiorite in the western sector of the intrusion. An additional gabbroic petrographic unit in the southern part of the massif is also recognized ([28] and the present study).

A set of Late Neoproterozoic N-S to N $70^{\circ}$ E-trending felsic to mafic dike swarms crosscut all country rocks including the older intrusives, with rhyolite dikes being volumetrically abundant (i.e., Tachkakacht rhyolite dated at $543 \pm 9$ Ma; [8]) (Figure 2). Less-common are the mafic volcanic and hypabyssal subvolcanic rocks, which consist primarily of comagmatic fine-grained and aphyric- to variably porphyritic microdiorite, andesite, and dolerite-diabase. Although undated, these basaltic to andesitic rocks appear to correlate with the regional Late Permian to Triassic igneous event described by [45-48]. Information regarding their mineralogy, crosscutting relationships, and geochemical attributes is summarized in [49].

\subsubsection{Volcanic and Volcaniclastic Rocks}

The sedimentary-pyroclastic succession of the Igoudrane area is initiated with the basal conglomerate filling ravines in the base of the upper Cryogenian (Figure 2). The overlying Ediacaran volcanic and volcaniclastic rocks occur as lavas and pyroclastic flow deposits. They consist of a succession of silicic ignimbrites, rhyolitic domes, rhyolitic and andesitic breccias, tuffs, and andesitic to rhyolitic lava flows. Dacite-rhyolite ignimbrites, which are interbedded within the monoclinal Imiter sequence and the unconformably overlying upper silicic sequence of the Ouarzazate group series [9,41], are widely exposed near the study area. Fiamme, sparse lithic fragments, and abundant phenocrysts of feldspar, biotite, and quartz occur in a vitroclastic matrix. Two episodes of ignimbrite flare up are recognized. These are from the oldest to the youngest: the $>500 \mathrm{~m}$ thick lithic- poor to lithicrich ignimbrites of the Imiter sequence [41] and the unconformably overlying Takhatert rhyolitic ignimbrites and related rhyolites of the Upper Silicic sequence. U-Pb zircon dating yields ages of $567 \pm 4$ to $565 \pm 7 \mathrm{Ma}$ for the lower ignimbrites [10], and 550-543 Ma for the upper ignimbrites and related rhyolites [2,8]. As for ignimbrites, tuffs with andesitic to rhyolitic composition are widespread through the Imiter sequence. Geochemically, all pyroclastic rocks at Igoudrane mine are characterized by a medium- to high-K calcalkaline, peraluminous signature, in accordance with other reported areas of the Anti-Atlas system [50].

\section{Mineralogy, Hydrothermal Alteration, Silver Mineralization, and Paragenesis}

In the mine area, the Ag-Pb-Zn-rich orebodies are located close to the supracrustal Imiter Fault (Figure 2) in the form of massive infills, and are hosted by a structurally complex system of NW- to E-W-trending sub-vertical north-dipping veins, veinlets, breccias, and stockwork zones (Figure 3). The mineralized structures are generally $<1 \mathrm{~m}$ wide and consist of subparallel arrays of discontinuous (Figure 3A,B), anastomosing veinlets along with development of hydrothermal breccia (Figure 3C). Veinlet-disseminated ores occur on 
the margins of the major veins in altered black shales. The Ag-Pb-Zn-bearing veins display comb, cockade, laminated, breccia, and crack-and-seal textures. Transtensional veins are mostly $0.5 \mathrm{~cm}$ to $3 \mathrm{~m}$ thick and extend laterally for as much several hundreds of meters (Figure 3D).

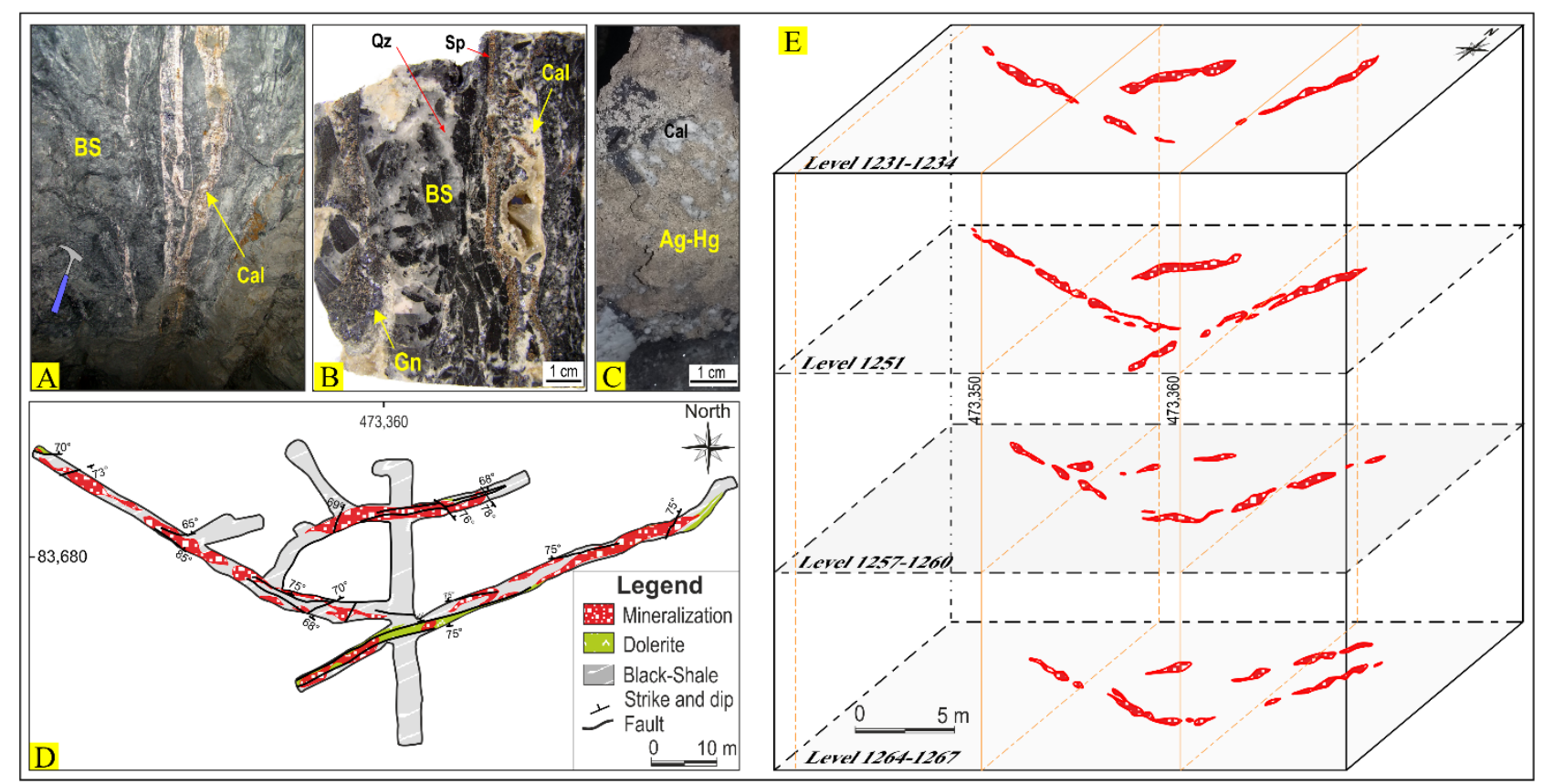

Figure 3. Key field relationships and hand specimen samples along with underground map and perspective 3D reconstitution documenting aspects of mineralogy, styles of open-space filling mineralization and textural variations of different ore types from the Igoudrane silver-rich $\pm \mathrm{Pb}$-Zn deposit. (A) Panoramic view, looking north, of an exploited silver-rich NW-SE-oriented and $80^{\circ} \mathrm{N}$-dipping trans-tensional vein displaying sharp contact with the Neoproterozoic black shale. (B) Late-stage base metal-rich vein crosscutting brecciated ore from the early quartz-silver stage. (C) High-grade monomict breccia with fragments of calcite cemented by native silver. (D) Geologic map of level 1251 (320-m depth) showing the distribution of footwall and hanging facies along with major structures and geometries of the orebodies. (E) Three-dimensional perspective view of the distribution and typical geometry of silver mineralization hosted by the late Neoproterozoic black shales.

Fault veins typically exhibit multiple phases of vein growth, with early phases brecciated and cemented by subsequent hydrothermal minerals, thus suggesting multiple episodes of dilation, fluid circulation, and deposition. Higher grade orebodies occur as vertically stacked arrays (Figure 3E), mainly controlled by the zones of intersection between NW- and NE-trending faults.

Ore is characterized by a complex paragenetic sequence of Ag-As-Sb sulfides and sulfosalts and $\mathrm{Pb}-\mathrm{Zn}-\mathrm{Cu}$ sulfides accompanied by variable amounts of calcite and fluorite as the dominant gangue minerals \pm quartz \pm dolomite (Figure 4 ). All the mineralized veins display similar mineral assemblages, but proportions of base metal sulfides relative to other Ag-bearing phases vary among the veins. Sulfides generally constitute less than $15 \mathrm{vol} \%$ of the veins, although higher concentrations (up to $\sim 30 \mathrm{vol} \%$ ) are locally observed. Silver minerals are abundant in all major veins and include native silver (Figure $4 \mathrm{~A}$ ), argentiferous tetrahedrite (i.e., freibergite-argentotennantite serie) (Figure 4B,C), acanthite (Figure 4D), polybasite, pyrargyrite, argentite, proustite, and $\mathrm{Ag}-\mathrm{Hg}$ amalgams (Figure 4B-D). Base metal sulfides are dominated by galena, sphalerite, pyrite-arsenopyrite, and chalcopyrite (Figure 4D,E). 

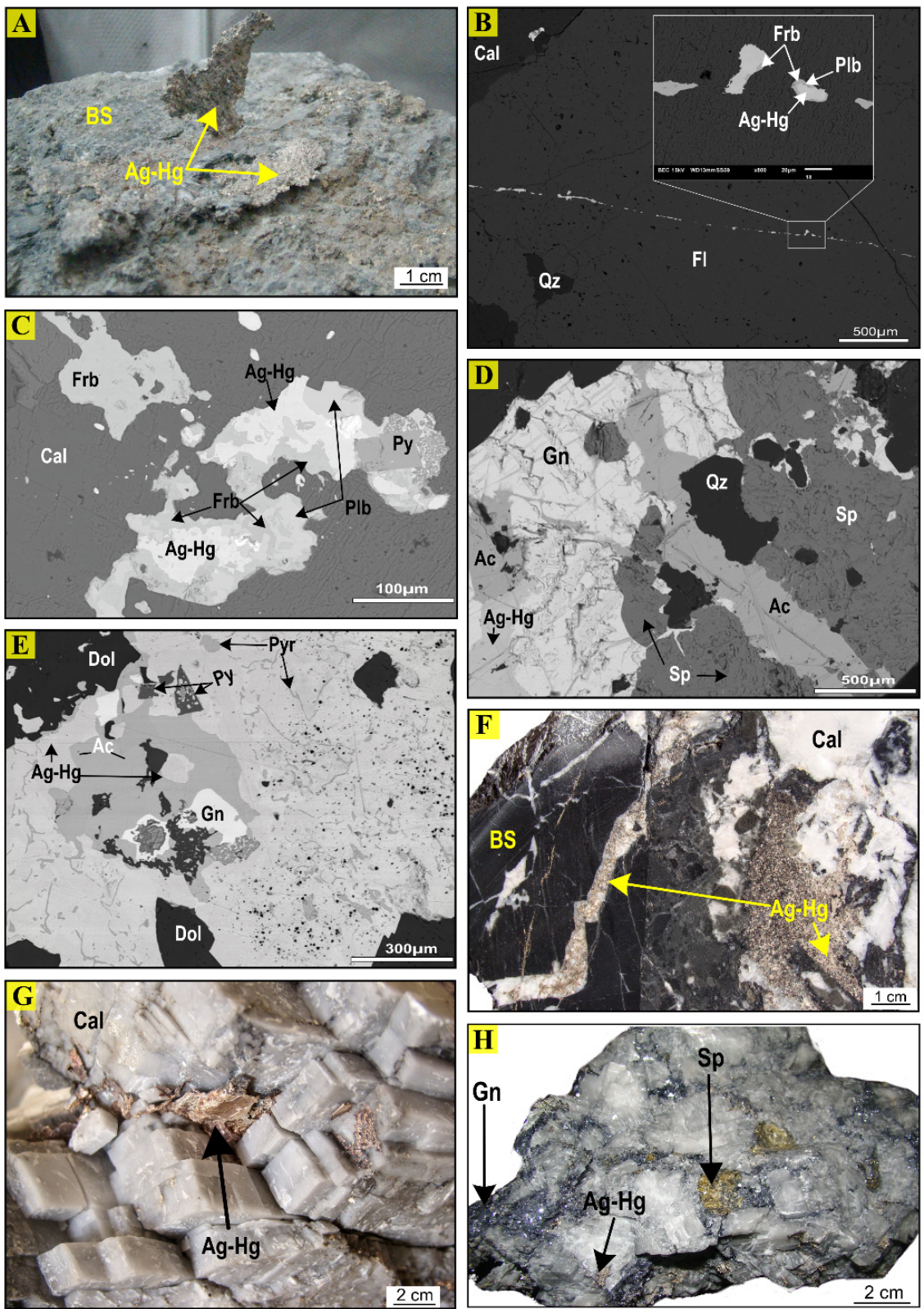

Figure 4. Representative rock slab photographs of hand specimens $(\mathbf{A}, \mathbf{F}-\mathbf{H})$, and back-scatter electron (BSE) images (B-E) showing mineral assemblages and ore textures of base metal and Ag-bearing sulfides and sulfosalts from the Igoudrane silver-rich $\pm \mathrm{Pb}-\mathrm{Zn}$ deposit. (A) Hand specimen of high-grade ore showing multiple flakes of native silver overgrowing on a brecciated rock. (B) Silverbearing veinlet crosscutting fluorite. The rectangle is a close-up of the aforementioned veinlet showing microscopic inclusions of freibergite, polybasite and $\mathrm{Ag}-\mathrm{Hg}$ amalgam set in a matrix of fluorite. (C) Clustering of euhedral to subhedral pyrite, freibergite, polybasite, and Ag- $\mathrm{Hg}$ amalgam set in a calcite rocky matrix. (D) Galena intergrown with sphalerite and quartz overprinted by acanthite and $\mathrm{Ag}-\mathrm{Hg}$ amalgam. (E) Intergrowths of pyrargyrite, acanthite, $\mathrm{Ag}-\mathrm{Hg}$ amalgam, pyrite, and galena with inclusions of dolomite. (F) Polished rock slab showing the coexistence of earlyquartz silver mineralization embedded in a calcite gangue interrupted by silver-bearing late-stage veining. (G) Hand sample of high-grade silver rich-ore showing brecciated calcite with native silver sealing the fractures and grain boundaries (i.e., crack and seal texture). (H) Hand sample from the late-stage ore showing brecciated-like texture with the relics of calcite being cemented by $\mathrm{Ag}-\mathrm{Hg}$ amalgam and sulfides (sphalerite, galena). Abbreviations: Ac = acanthite; Bs = black shale; $\mathrm{Cal}=$ calcite; $\mathrm{Dol}=$ dolomite; $\mathrm{Gn}$ = galena; $\mathrm{Fl}=$ fluorite; $\mathrm{Frb}=$ freibergite; $\mathrm{Plb}=$ polybasite; $\mathrm{Qz}=$ quartz; $\mathrm{Sp}=$ sphalerite; $\mathrm{Pyr}=$ pyrargyrite; $\mathrm{Py}=$ pyrite . 
Wall-rock hydrothermal alteration is weak without development of visible alteration halos even alongside the mineralized quartz and carbonate veins and veinlets. Where alteration is observable, it is restricted to weak sericitization, and to lesser extent chloritization where the nature of the protolith is mafic. The resulting mineral assemblages consist predominantly of quartz and carbonates (mainly calcite) with a minor chlorite, sericite, and pyrite-arsenopyrite overprints. Silicification is the early alteration type (Figure 4F) and led to development of milky and gray quartz veins to which the early silver-bearing stage I is related to. This stage, which gave rise predominantly to development of NEtrending dextral mineralized veins filled by quartz and associated silver-baring sulfide and sulfosalt assemblages, occurred in response to NW-SE to WNW-ESE transpressional tectonics $[4,42,43,51]$. Conversely, carbonitization is by far the dominant alteration type (Figure 4G) in the Igoudrane mine. The resulting dominantly NW- to E-W-trending, north dipping argentiferous veins and veinlets \pm calcite \pm fluorite \pm base metal sulfide are assumed to have occurred from the reactivation and filling of the earlier vein system under NE-SW transtensional regime in response to N-S to NE-SW shortening [42,43]. Based on mineral assemblages and crosscutting relationships, two sub-stages of silver \pm base metal mineralization are recognized within stage II. Sub-stage II- 1 consists mostly of silverbearing sulfides and sulfosalts accompanied predominantly by calcite, whereas substage II-2 contains silver ore enclosed in a gangue of fluorite and quartz in association with galena, sphalerite, pyrite, and chalcopyrite (Figure $4 \mathrm{H}$ ). Late-stage base metal-quartz-carbonate sub-stage II.3 veins (Figure 3B) cut all previous veins and breccia. The idealized paragenetic sequence for Igoudrane deposit is shown in Figure 5.

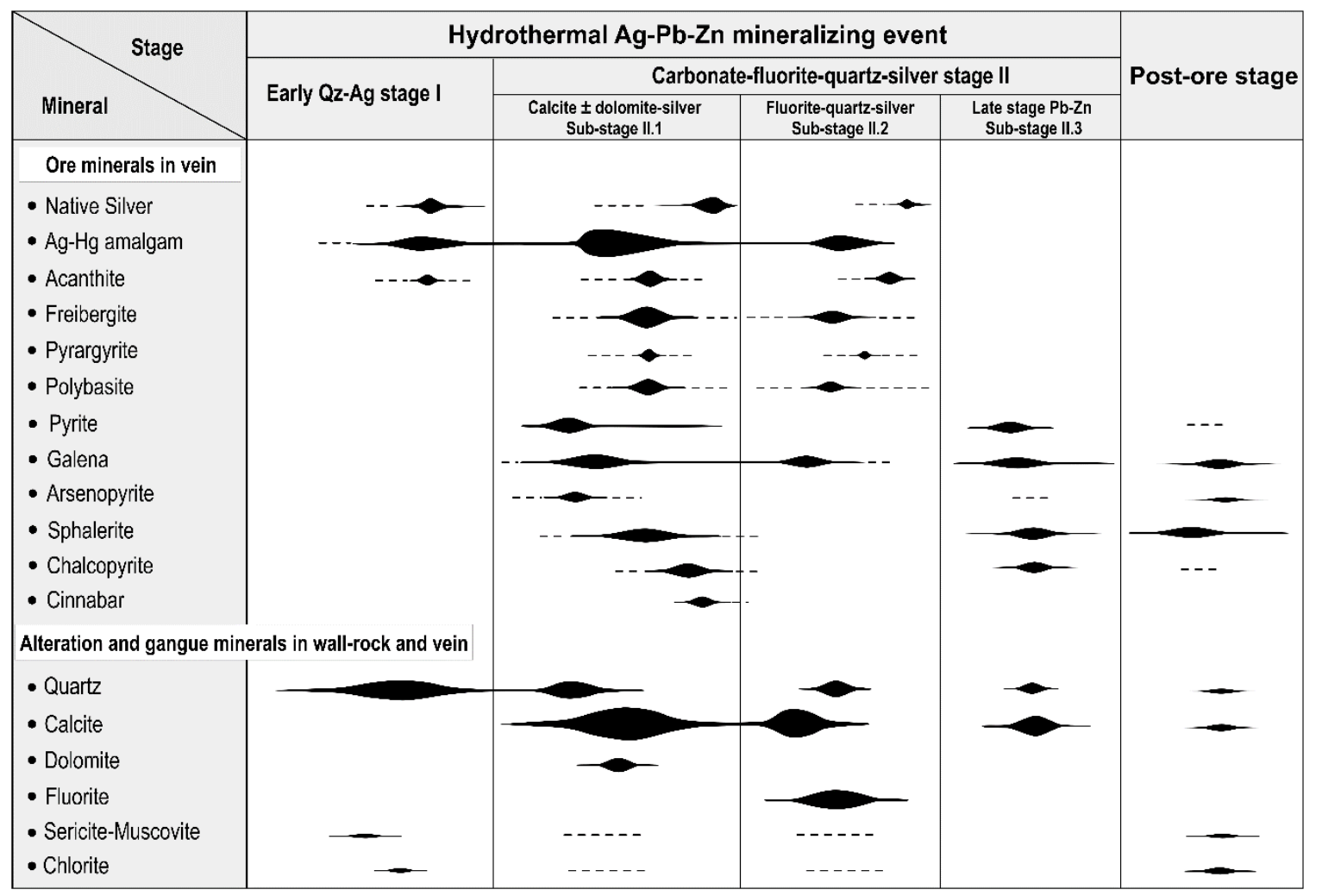

Figure 5. Summary of the paragenetic sequence identified at the Igoudrane silver-rich $\pm \mathrm{Pb}-\mathrm{Zn}$ deposit. Horizontal lines indicate relative timing of mineral formation. Line thicknesses represent, schematically, the relative abundance of precipitated minerals. Dotted lines indicate uncertainties. 


\section{Sampling and Analytical Methods}

The samples analyzed in this contribution includes whole-rock specimens and mineral separates collected from surface outcrops, high-grade open pits, underground workings, and drill cores to obtain a representative suite of the principal minerals deposited throughout the mineral paragenesis (Figure 5). Whole-rock samples (rhyolite, ignimbrite, tuff, granodiorite, diorite, gabbro, and black-shales) were collected from visibly fresh outcrop away from the Igoudrane ore veins. The selected specimens including the ore were split for petrography, mineralogy, mineral chemistry, and isotopic geochemistry. Petrographic examinations were conducted on a standard transmitted- and reflected-light microscope at university of Oujda (Morocco). Scanning electron microscope (SEM) investigations were carried out using a Jeol JSM-7500F equipped with an energy dispersive detector (EDS), and a Zeiss Sigma 300 FEG equipped with two Bruker EDS detectors at the University of Namur (Belgium). Beam operating conditions were an acceleration voltage of $20 \mathrm{kV}$ and a probe current of $2.3 \mathrm{nA}$. Backscatter electron (BSE) and CL imaging were used to locate and study textural relationships in the veins that were too small for examination by optical petrography.

Whole-rock major and trace element compositions were determined at Activation Laboratory Ltd. (Actlabs, Ancaster, ON, Canada) by Li metaborate/tetraborate fusioninductively coupled plasma (FUS-ICP) for major elements, Li metaborate/tetraborate fusion-inductively coupled plasma-mass spectrometry (FUS-ICP/MS) for trace elements including the rare earth elements (REE), fusion-ion selective electrode (FUS-ISE) for F, and infrared spectroscopy for total $\mathrm{S}$ and total digestion-ICP-MS to refine $\mathrm{Pb}$ values.

Chemical compositions of major sulfide and sulfosalt minerals along with Ag-Hg amalgams were determined using a CAMECA SX-100 electron probe microanalyzer (EPMA) equipped with four wavelength and energy-dispersive spectrometers WDS and EDS spectrometers at the microanalysis center CAMPARIS UPMC-INSU (Sorbonne Université, France). Quantitative analyses were carried out using a $25 \mathrm{kV}$ accelerating voltage, a $20 \mathrm{nA}$ beam current, a 2-5 $\mu \mathrm{m}$ beam diameter, and counting times of $10 \mathrm{~s}$ for peak measurements. With regard to acanthite, proustite, and other-sensitive silver minerals, a defocused beam $(10-15 \mu \mathrm{m})$ of $4 \mathrm{nA}$ was applied due to their rapid decomposition under the electron beam. The element lines used for analysis included $\mathrm{K} \alpha$ lines-S, Cu, Ni, Co, Fe; L $\alpha$ lines-As, Zn, $\mathrm{Se}, \mathrm{Ag}, \mathrm{Cd}, \mathrm{Sb} ; \mathrm{M} \alpha$ lines- $\mathrm{Hg}$, Bi; $\mathrm{L} \beta$ lines- $\mathrm{Sn} ; \mathrm{M} \beta$ lines- $\mathrm{Pb}$. The following standards were used for calibration: sphalerite (for $\mathrm{S}, \mathrm{Zn}$ ), pure $\mathrm{Cu}$ (for $\mathrm{Cu}$ ), $\mathrm{NiO}$ (for $\mathrm{Ni}$ ), pure $\mathrm{Co}$ (for $\mathrm{Co}$ ), pyrite (for $\mathrm{Fe}$ ), AsGa (for As), pure Se (for Se), pure Ag (for Ag), pure Cd (for Cd), $\mathrm{Sb} 2 \mathrm{S3}$ (for $\mathrm{Sb}$ ), Cinnabarite (for $\mathrm{Hg}$ ), $\mathrm{SnO}_{2}$ (for $\mathrm{Sn}$ ), $\mathrm{PbS}$ (for $\mathrm{Pb}$ ), pure $\mathrm{Bi}$ (for $\mathrm{Bi}$ ).

The trace element compositions of calcite and fluorite were measured on single crystals by laser ablation-inductively coupled plasma mass spectrometry (LA-ICPMS) at the Department of Geosciences, University of Bremen (Germany). Calcium was used as an internal standard. For fluorites stochiometric $\mathrm{Ca}$ was assumed; for calcite the $\mathrm{Ca}$ concentrations were corrected for measured $\mathrm{Ca}, \mathrm{Mg}$, $\mathrm{Fe}$, and $\mathrm{Mn}$ abundances by normalizing their total to $100 \%(\mathrm{Ca}+\mathrm{Mg}+\mathrm{Fe}+\mathrm{Mn})$ carbonate. Details of the data acquisition and quality control are described in [52].

Petrographic observations and temperature measurements of fluid inclusions (FIs) along with bulk FIs analysis were made on doubly polished wafers from Ag-mineralized samples from the Igoudrane deposit to quantify physical and chemical characteristics of the mineralizing fluids. Wafers were inspected under a petrographic Olympus ${ }^{\circledR}$ BX-50 optical microscope equipped with a ultralong working distance objectives and Qimaging Micropublisher $5 \mathrm{Mp}$ digital camera. Microthermometric data were acquired on a Linkam THMSG-600 stage coupled to the Olympus ${ }^{\circledR}$ microscope equipped with ultralong working distance objectives, at the Crustal Fluids Laboratory of the Centro de Geociencias at UNAM in Querétaro (Mexico). This stage permits the observation of fluid inclusion phase transitions from $-193^{\circ}$ to $+600{ }^{\circ} \mathrm{C}$ with an accuracy of $\pm 0.1^{\circ} \mathrm{C}$. The stage was calibrated using Synflinc ${ }^{\circledR}$ synthetic FIs and ultrapure chemicals with fixed melting points. The gas contents of aqueous-bearing FIs was determined by Raman microspectroscopy (CINESTAV-Conacyt laboratory) using a High Resolution Labram type (Dilor) equipped 
with a Notch filter and a grating (1800 grooves per $\mathrm{mm})$ to make it luminous. The detector was a CCD cooled at $-30^{\circ} \mathrm{C}$; the exciting radiation was provided by an Ar+ laser (Type 2020, Spectraphysics) at $514.5 \mathrm{~nm}$. Spectral resolution was approximately $2 \mathrm{~cm}^{-1}$. The accumulation time, laser power, and confocal aperture were modified for each inclusion measurement to obtain an optimum signal-to-noise ratio. For the decrepitation method of FIs analysis, four calcite samples were carefully separated from thick sections. Samples were crushed and sieved between 45 to 60 mesh. The non-magnetic fraction was separated using a Frantz isodynamic magnet. Final calcite populations were hand-picked under a binocular microscope. The samples were then cleaned with ultra-pure in an ultrasonic microwave oven for $5 \mathrm{~min}$. Calcite samples were analyzed at the Crustal Fluid Laboratory using a BGS model 205 decriptometer, which consists of an open silica tube equipped with a sensitive microphone connected to the silica tube and a furnace, where the sample is placed inside the silica tube. Before and after each sample analysis, three standard tests were run to ensure correct functioning of the equipment.

Carbon and oxygen isotope analyses of hand-picked calcite separates were carried out at the Radiometric Dating and Stable Isotope Research laboratory at the University of Erlangen-Nuremberg (Germany) on hand-picked calcite separates. Carbonate powders were reacted with $100 \%$ phosphoric acid at $70{ }^{\circ} \mathrm{C}$ using a Gasbench II connected to a ThermoFisher Delta V Plus mass spectrometer. Isotopic data are reported per mil (\%o) relative to the Standard Mean Ocean Water (V-SMOW) for oxygen and to the PeeDee Belemnite (V-PDB) for carbon [53]. Reproducibility and accuracy were monitored by replicate analysis of laboratory standards calibrated by assigning a $\delta^{13} \mathrm{C}$ of $+1.95 \%$ to NBS19 and $-47.3 \%$ to IAEACO 9 and a $\delta^{18} \mathrm{O}$ of $-2.20 \%$ to NBS19 and $-23.2 \%$ o to NBS18. Analytical precision $(1 \sigma)$ was calculated on the basis of multiple measurements of wellcharacterized carbonate standards between sample runs and was better than $0.01 \%$ for $\delta^{13} \mathrm{C}$ and $0.02 \%$ for $\delta^{18} \mathrm{O}$, after corrections for scale compression.

Strontium isotopes analyses of carbonates were performed at Laboratoire G-Time (Université Libre de Bruxelles, Belgium). Samples were ashed in porcelain crucibles at $650{ }^{\circ} \mathrm{C}$ in a muffle furnace by step heating for up to $8 \mathrm{~h}$. Strontium was extracted from the ashed samples and purified following the protocol described in [54], and measured on a Nu Plasma Multi-Collector ICP-MS (Nu015 from Nu Instruments, Wrexham, UK). Repeated analyses of the NBS 987 standard yielded ${ }^{87} \mathrm{Sr} /{ }^{86} \mathrm{Sr}=0.710246 \pm 0.000024$. Mass fractionation was corrected by internal normalization $\left({ }^{86} \mathrm{Sr} /{ }^{88} \mathrm{Sr}=0.1194\right)$ for all data. All measurements were normalized externally using a standard bracketing method with the recommended value of ${ }^{87} \mathrm{Sr} /{ }^{86} \mathrm{Sr}=0.710248$ for NBS987 [55]. Procedural blanks were considered negligible. ${ }^{87} \mathrm{Sr} /{ }^{86} \mathrm{Sr}$ value is reported with a $2 \sigma$ error.

\section{Analytical Results}

\subsection{Host-Rock Geochemistry}

The discrimination diagram of [56] confirms that the volcanic and intrusive rocks hosting the Igoudrane mineralization are of basaltic to rhyolitic composition (Table 1, Figure 6A). Geochemically, the samples plot in the field of metaluminous to peraluminous (Figure 6B) high-K calc-alkaline series (Figure 6C), and display subparallel similar slightly to moderately chondrite-normalized light REE-enriched patterns $\left(\mathrm{La} / \mathrm{Sm}_{\mathrm{CN}}=1.11-7.03\right.$ and $\left.\mathrm{La} / \mathrm{Yb}_{\mathrm{CN}}=2.46-21.03\right)$ with pronounced negative Eu anomalies $\left(\mathrm{Eu} / \mathrm{Eu}^{*}=0.16-0.97\right)$ (Figure 6D). This geochemical similarity and their stratigraphic relationships suggest that the different host rocks are petrogenetically related, with the felsic and mafic counterparts being potentially derived from the same differentiating parent magma. More importantly, the trace element patterns for these rocks, with depletions of $\mathrm{Nb}$, and $\mathrm{Ta}$, along with the $\mathrm{Zr} / \mathrm{Nb}$ (12.6-26.0) and $\mathrm{Zr} / \mathrm{Y}$ ratios (2.2-13.1) and the diagram of [57] (Figure 6E) confirm that the Igoudrane igneous and pyroclastic rocks formed in an arc setting as initially proposed by previous authors $[7,8,12,28]$. 
Table 1. Representative whole-rock major- and trace-element compositions of major igneous and pyroclastic rocks from the Igoudrane silver-rich $\pm \mathrm{Pb}-\mathrm{Zn}$ deposit.

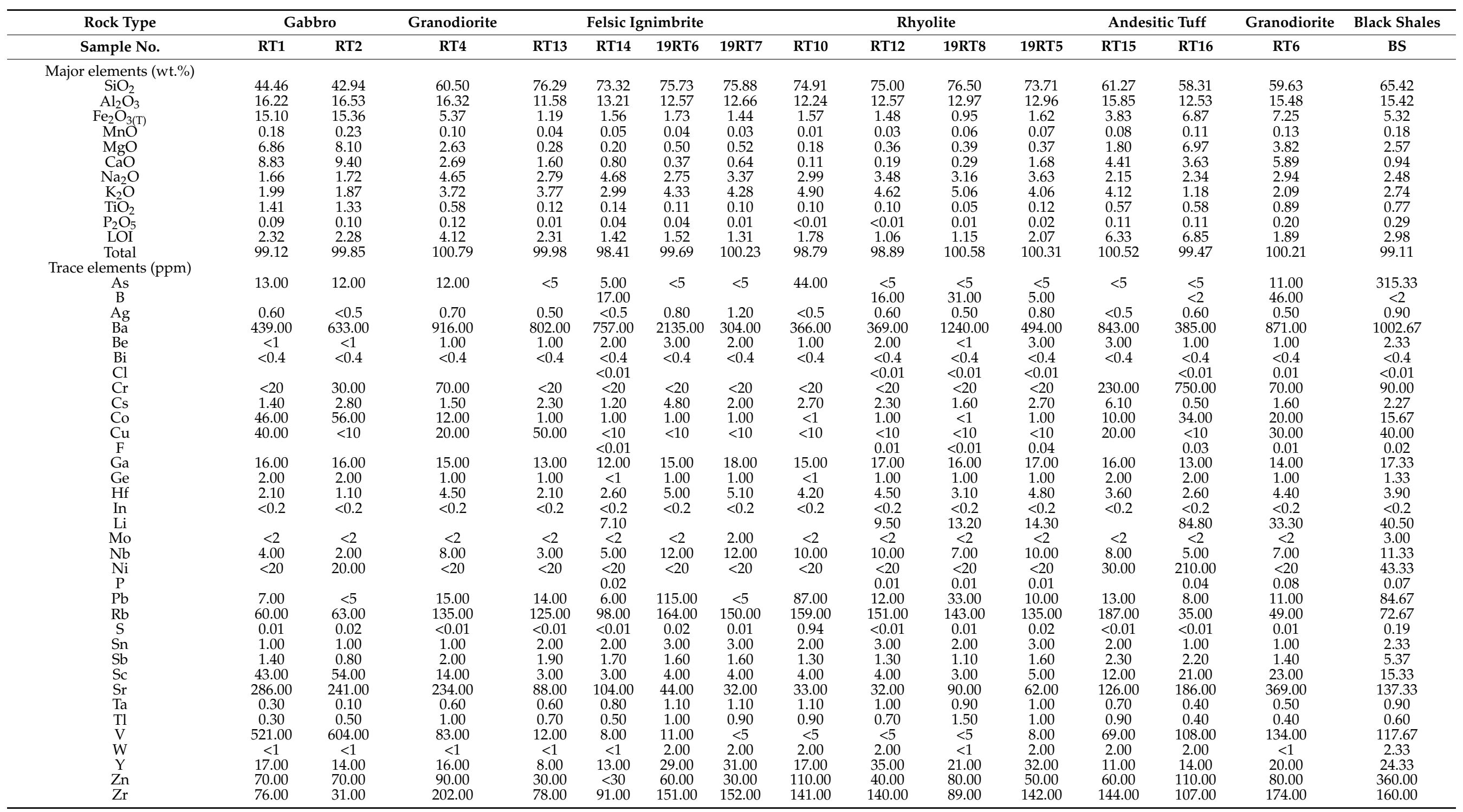


Table 1. Cont.

\begin{tabular}{|c|c|c|c|c|c|c|c|c|c|c|c|c|c|c|c|}
\hline \multirow{2}{*}{$\begin{array}{l}\text { Rock Type } \\
\text { Sample No. }\end{array}$} & \multicolumn{2}{|c|}{ Gabbro } & \multirow{2}{*}{$\begin{array}{c}\text { Granodiorite } \\
\text { RT4 }\end{array}$} & \multicolumn{4}{|c|}{ Felsic Ignimbrite } & \multicolumn{4}{|c|}{ Rhyolite } & \multicolumn{2}{|c|}{ Andesitic Tuff } & \multirow{2}{*}{$\begin{array}{c}\text { Granodiorite } \\
\text { RT6 }\end{array}$} & \multirow{2}{*}{$\begin{array}{c}\text { Black Shales } \\
\text { BS }\end{array}$} \\
\hline & RT1 & RT2 & & RT13 & RT14 & 19RT6 & 19RT7 & RT10 & RT12 & 19RT8 & 19RT5 & RT15 & RT16 & & \\
\hline $\mathrm{La}$ & 11.20 & 4.80 & 30.50 & 17.00 & 38.10 & 31.50 & 33.10 & 24.10 & 38.70 & 34.30 & 33.00 & 22.50 & 20.30 & 23.00 & 34.23 \\
\hline $\mathrm{Ce}$ & 24.60 & 12.40 & 58.80 & 30.90 & 68.60 & 66.90 & 69.30 & 51.00 & 71.20 & 53.10 & 70.60 & 41.10 & 38.70 & 48.30 & 69.77 \\
\hline $\operatorname{Pr}$ & 3.18 & 1.89 & 6.29 & 3.20 & 6.68 & 7.86 & 8.18 & 5.69 & 9.18 & 6.90 & 8.38 & 4.44 & 4.31 & 5.59 & 7.70 \\
\hline $\mathrm{Nd}$ & 14.20 & 10.10 & 24.30 & 11.20 & 21.70 & 29.40 & 30.30 & 19.40 & 34.30 & 23.60 & 31.50 & 14.80 & 15.90 & 21.60 & 28.80 \\
\hline $\mathrm{Sm}$ & 3.80 & 2.80 & 4.30 & 2.20 & 3.50 & 5.90 & 6.10 & 3.70 & 7.00 & 4.30 & 6.80 & 3.10 & 3.30 & 4.30 & 5.77 \\
\hline $\mathrm{Eu}$ & 1.07 & 0.94 & 1.02 & 0.47 & 0.63 & 0.37 & 0.36 & 0.17 & 0.33 & 0.48 & 0.42 & 0.78 & 0.96 & 0.96 & 1.35 \\
\hline $\mathrm{Gd}$ & 4.10 & 3.50 & 3.60 & 1.70 & 2.60 & 5.10 & 5.30 & 2.70 & 5.90 & 3.50 & 5.60 & 2.70 & 2.80 & 4.40 & 5.13 \\
\hline $\mathrm{Tb}$ & 0.60 & 0.50 & 0.50 & 0.30 & 0.40 & 0.90 & 0.90 & 0.50 & 1.00 & 0.60 & 1.00 & 0.40 & 0.50 & 0.70 & 0.80 \\
\hline Dy & 3.90 & 3.40 & 3.20 & 1.50 & 2.40 & 5.10 & 5.30 & 3.30 & 5.80 & 3.10 & 5.60 & 2.30 & 2.90 & 4.00 & 4.83 \\
\hline Ho & 0.80 & 0.60 & 0.60 & 0.30 & 0.50 & 1.00 & 1.00 & 0.60 & 1.10 & 0.60 & 1.10 & 0.50 & 0.60 & 0.80 & $\begin{array}{l}0.90 \\
0.00\end{array}$ \\
\hline $\mathrm{Tm}$ & 0.29 & 0.24 & 0.27 & 0.12 & 0.20 & 0.45 & 0.46 & 0.33 & 0.48 & 0.28 & 0.44 & 0.19 & 0.23 & 0.32 & 0.39 \\
\hline $\mathrm{Yb}$ & 1.80 & 1.40 & 1.70 & 0.90 & 1.30 & 3.00 & 3.10 & 2.10 & 3.30 & 2.20 & 3.10 & 1.20 & 1.40 & 2.10 & 2.53 \\
\hline $\mathrm{Lu}$ & 0.21 & 0.17 & 0.22 & 0.15 & 0.18 & 0.46 & 0.48 & 0.31 & 0.55 & 0.33 & 0.47 & 0.17 & 0.21 & 0.31 & 0.35 \\
\hline$\sum$ REY & 88.75 & 58.54 & 153.00 & 78.74 & 161.09 & 190.04 & 197.98 & 132.90 & 217.04 & 156.29 & 203.11 & 106.48 & 107.71 & 138.58 & 189.49 \\
\hline Th & 2.70 & 0.60 & 6.70 & 10.70 & 12.10 & 11.50 & 12.50 & 12.50 & 12.60 & 12.20 & 11.00 & 6.80 & 4.70 & 4.50 & 9.27 \\
\hline $\mathrm{U}$ & 1.10 & 0.70 & 3.50 & 4.10 & 4.90 & 5.10 & 5.30 & 5.00 & 6.00 & 5.60 & 5.00 & 4.70 & 2.50 & 2.10 & 2.43 \\
\hline$(\mathrm{La} / \mathrm{Sm})_{\mathrm{CN}}$ & 1.90 & 1.11 & 4.58 & 4.99 & 7.03 & 3.45 & 3.50 & 4.20 & 3.57 & 5.15 & 3.13 & 4.69 & 3.97 & 3.45 & 3.83 \\
\hline$(\mathrm{La} / \mathrm{Yb})_{\mathrm{CN}}$ & 4.46 & 2.46 & 12.87 & 13.55 & 21.02 & 7.53 & 7.66 & 8.23 & 8.41 & 11.18 & 7.64 & 13.45 & 10.40 & 7.86 & 9.69 \\
\hline$(\mathrm{La} / \mathrm{Lu})_{\mathrm{CN}}$ & 5.72 & 3.03 & 14.86 & 12.15 & 22.68 & 7.34 & 7.39 & 8.33 & 7.54 & 11.14 & 7.52 & 14.18 & 10.36 & 7.95 & 10.48 \\
\hline$\left(\mathrm{Eu} / \mathrm{Eu}^{*}\right)_{\mathrm{CN}}$ & 0.83 & 0.92 & 0.79 & 0.74 & 0.64 & 0.21 & 0.19 & 0.16 & 0.16 & 0.38 & 0.21 & 0.82 & 0.97 & 0.67 & 0.76 \\
\hline
\end{tabular}

Abbreviations: $n=$ Number of analyses; $\mathrm{CN}=$ Chondrite-normalized; Eu/Eu* $=\mathrm{EuN} /(\mathrm{SmN} \times \mathrm{GdN})^{0.5}$. 

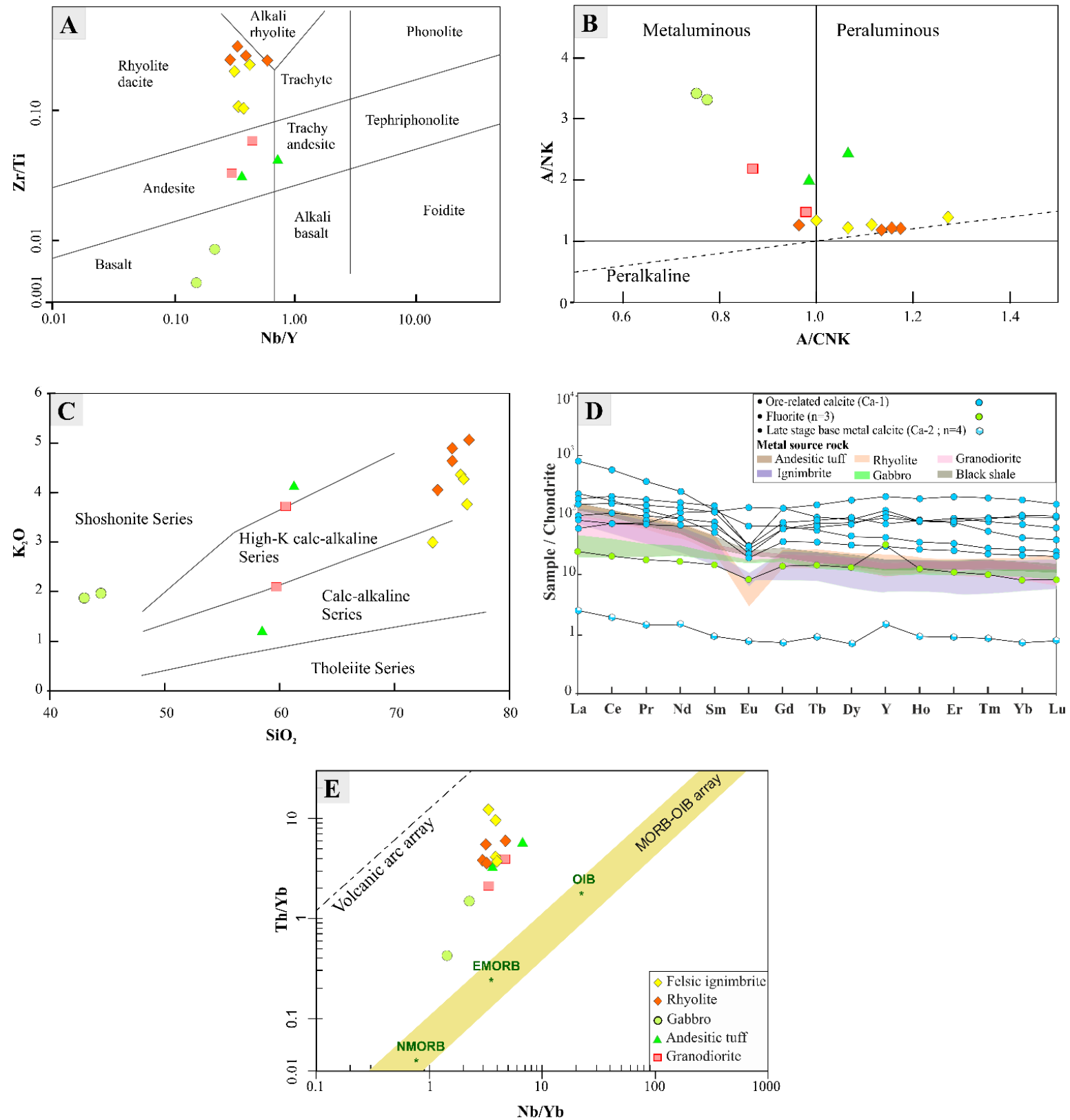

Figure 6. Geochemical discrimination diagrams showing the chemical affinities and geodynamic setting of the Igoudrane igneous and pyroclastic rocks. (A) Nb/Y versus $\mathrm{Zr} / \mathrm{Ti}$ classification diagram from [56] modified by [58] with the plotted compositions indicating compositions from basalt to rhyolite. (B) A/CNK versus A/NK diagram of [59] displaying the metaluminous to peraluminous features of the analyzed petrographic units. (C) $\mathrm{SiO}_{2}$ versus $\mathrm{K}_{2} \mathrm{O}$ diagram of [60] displaying the high-K calc-alkaline affinity of the analyzed petrographic units. (D) Chondrite-normalized REE patterns of representative hydrothermal carbonates and fluorite compositions compared to potential rock sources. Normalizing data are from [61]. (E) $\mathrm{Th} / \mathrm{Yb}$ versus $\mathrm{Nb} / \mathrm{Yb}$ diagram from [57] useful for identifying the geodynamic context with all compositions plotted within the volcanic arc array.

\subsection{Silver- and Base Metal-Bearing Mineral Chemistry}

Silver minerals are abundant in all major veins and include freibergite, pyrargyrite, pearceite-polybasite, argentite, acanthite, proustite, and more importantly native silver. Base metal sulfides include in order of decreasing abundance galena, sphalerite, chalcopyrite, pyrite, and arsenopyrite. EPMA analyses and related calculated structural formulae of the major Ag-bearing minerals are presented in Table 2. 


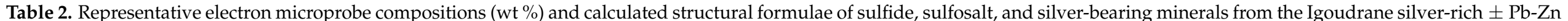
deposit (n.d.= not detected).

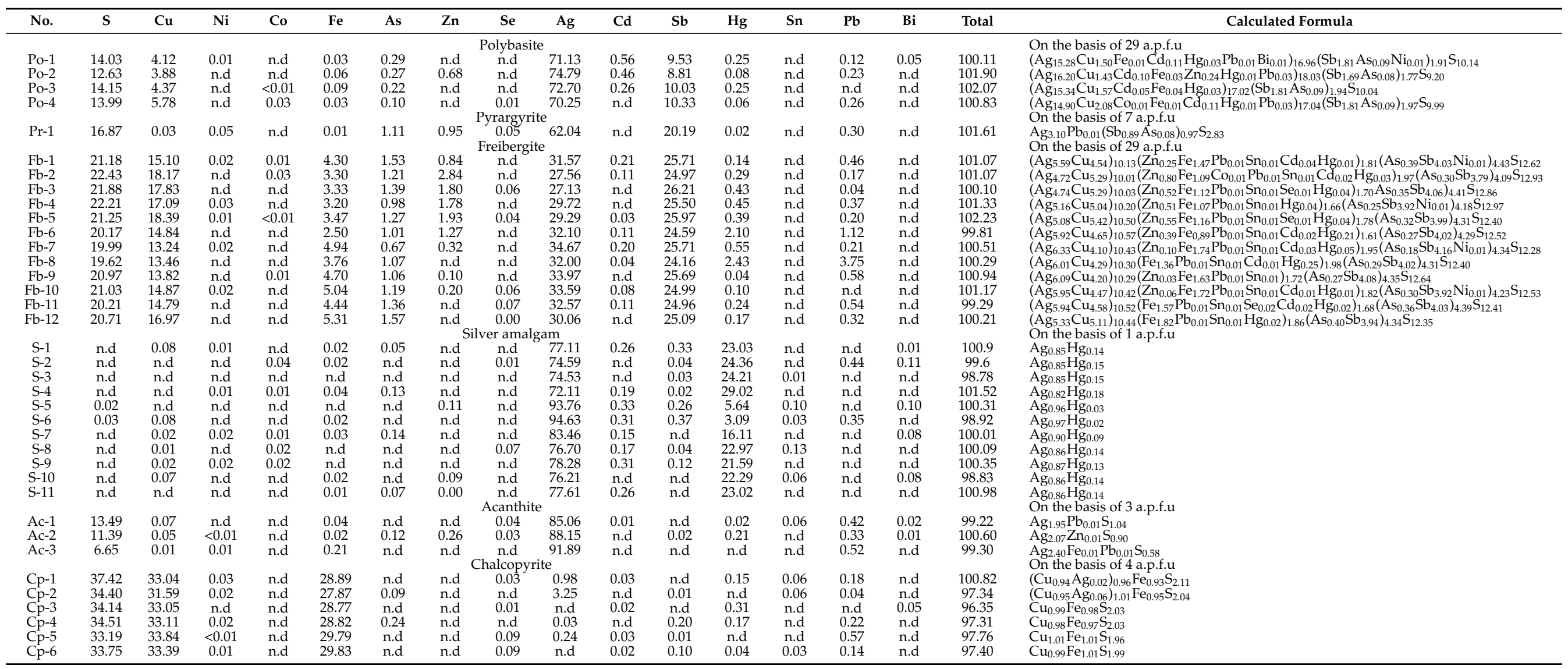


Table 2. Cont.

\begin{tabular}{|c|c|c|c|c|c|c|c|c|c|c|c|c|c|c|c|c|c|}
\hline No. & $\mathrm{s}$ & $\mathrm{Cu}$ & $\mathrm{Ni}$ & Co & $\mathrm{Fe}$ & As & $\mathrm{Zn}$ & Se & $\mathrm{Ag}$ & $\mathrm{Cd}$ & $\mathrm{Sb}$ & $\mathrm{Hg}$ & Sn & $\mathrm{Pb}$ & $\mathbf{B i}$ & Total & Calculated Formula \\
\hline & & & & & & & & Galena & & & & & & & & & \multirow{19}{*}{ 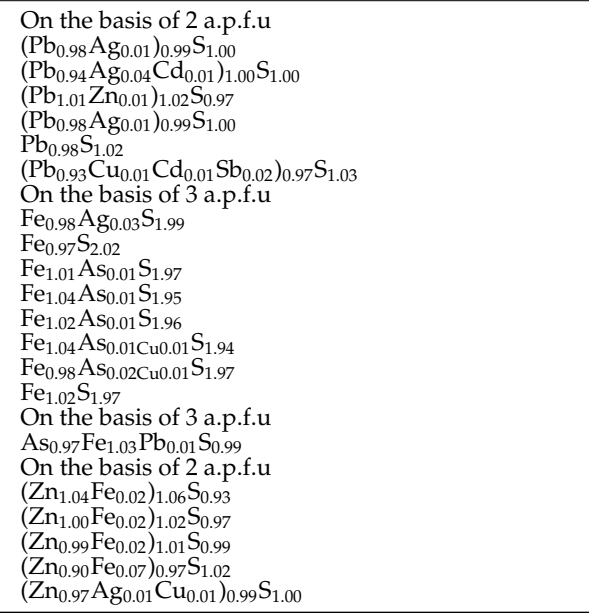 } \\
\hline Gn-1 & 13.44 & n.d & 0.04 & n.d & 0.04 & 0.02 & n.d & n.d & 0.45 & n.d & 0.16 & n.d & 0.24 & 85.70 & n.d & 100.09 & \\
\hline Gn-2 & 13.78 & n.d & n.d & n.d & 0.05 & n.d & n.d & n.d & 1.99 & 0.44 & 0.04 & 0.11 & 0.09 & 84.09 & n.d & 100.58 & \\
\hline Gn-3 & 13.02 & n.d & n.d & 0.04 & 0.04 & n.d & 0.27 & n.d & n.d & 0.21 & n.d & 0.10 & n.d & 87.09 & n.d & 100.77 & \\
\hline $\mathrm{Gn}-4$ & 13.81 & n.d & n.d & n.d & 0.07 & n.d & n.d & n.d & 0.52 & 0.21 & $<0.01$ & 0.03 & 0.07 & 87.06 & n.d & 101.77 & \\
\hline Gn-6 & 14.57 & 0.32 & $<0.01$ & n.d & n.d & n.d & n.d & $\begin{array}{l}0.02 \\
\text { Pyrite }\end{array}$ & n.d & 0.27 & 1.12 & n.d & 0.02 & 84.81 & n.d & 101.12 & \\
\hline Py-1 & 52.22 & 0.10 & n.d & n.d & 44.79 & n.d & n.d & 0.01 & 2.23 & n.d & 0.09 & 0.11 & n.d & 0.10 & n.d & 99.64 & \\
\hline Py-2 & 55.06 & 0.06 & 0.01 & n.d & 46.05 & 0.20 & n.d & 0.05 & 0.07 & n.d & 0.05 & n.d & n.d & 0.15 & n.d & 101.69 & \\
\hline$P y-3$ & 51.36 & 0.12 & $<0.01$ & n.d & 46.11 & 0.83 & n.d & 0.01 & n.d & 0.16 & 0.18 & 0.07 & n.d & 0.03 & n.d & 98.88 & \\
\hline Py-4 & 49.84 & 0.10 & 0.03 & n.d & 46.37 & 0.48 & n.d & $<0.01$ & n.d & n.d & 0.10 & 0.02 & $<0.01$ & 0.38 & n.d & 97.33 & \\
\hline Py-5 & 50.73 & 0.21 & n.d & n.d & 46.08 & 0.69 & n.d & n.d & n.d & n.d & 0.10 & 0.02 & 0.11 & 0.77 & n.d & 98.70 & \\
\hline Py-7 & 51.83 & 0.62 & 0.10 & n.d & 44.72 & 1.14 & 0.10 & 0.02 & 0.21 & 0.05 & 0.21 & n.d & 0.01 & 0.24 & n.d & 99.26 & \\
\hline Py-8 & 51.35 & 0.19 & n.d & n.d & 46.14 & 0.29 & n.d & $\begin{array}{l}\text { n.d } \\
\text { Arsenopyrit }\end{array}$ & 0.16 & n.d & 0.05 & n.d & 0.04 & 0.13 & n.d & 98.35 & \\
\hline Asp & 18.96 & n.d & 0.02 & n.d & 34.34 & 43.62 & n.d & 0.15 & 0.35 & n.d & n.d & n.d & 0.06 & 0.63 & 0.01 & 98.13 & \\
\hline Sp-1 & 29.31 & 0.03 & $<0.01$ & 0.02 & 1.13 & 0.15 & 66.72 & $\begin{array}{l}\text { Sphalerite } \\
\text { n.d }\end{array}$ & n.d & n.d & n.d & 0.15 & 0.07 & n.d & 0.04 & 97.63 & \\
\hline $\mathrm{Sp}-2$ & 31.46 & 0.01 & 0.01 & 0.01 & 1.35 & 0.22 & 65.94 & 0.03 & n.d & 0.06 & 0.06 & n.d & n. & 0.14 & n.d & 99.29 & \\
\hline $\mathrm{Sp}-3$ & 32.79 & n.d & 0.04 & n.d & 0.97 & n.d & 66.30 & 0.03 & n.d & 0.27 & n.d & n.d & n.d & n.d & n.d & 100.41 & \\
\hline Sp-4 & 34.03 & n.d & 0.01 & n.d & 3.89 & 0.21 & 61.28 & 0.12 & 0.27 & 0.22 & 0.07 & 0.00 & 0.03 & 0.08 & n.d & 100.21 & \\
\hline Sp-5 & 33.11 & 0.40 & n.d & n.d & 0.22 & 0.32 & 65.78 & 0.04 & 0.57 & 0.34 & 0.40 & 0.12 & n.d & n.d & n.d & 101.29 & \\
\hline
\end{tabular}


Native silver and Ag-Hg amalgams are by far the most exploited and economically the most attractive argentiferous resource in the Igoudrane deposit. Where present, native silver occurs either as disseminated to interconnected massive flakes in calcite up to several Kt of silver ounces or as arborescent and dendritic stringers cutting across the gangue carbonate (Figure 4G). Filamentous silver lining open cavities (i.e., wire silver) is also commonly present in the silver-bearing veins. Except for the wire silver which exhibits almost pure composition, the native silver from the Igoudrane deposit displays significant variations in $\mathrm{Hg}$ abundances with concentrations ranging from 3.09 to 29.02 wt \% (Table 2), and therefore should be referred to as $\mathrm{Ag}-\mathrm{Hg}$ amalgam rather than native silver sensu stricto.

Argentiferous tetrahedrite of the freibergite-tennantite series (Figure 4C) is among the most abundant sulfosalt mineral in the deposit. Compositionally, argentiferous tetrahedrite crystals show a large range in $\mathrm{Ag}(27.1-34.7 \mathrm{wt} \%), \mathrm{Sb}(24.1-26.21 \mathrm{wt} \%), \mathrm{Cu}$ (13.24 to $18.39 \mathrm{wt} \%)$, and As (0.7-1.6 wt \%) contents (Table 2), allowing their classification as freibergite. Fe and $\mathrm{Zn}$ contents show significant variations ranging from 2.50 to $5.31 \mathrm{wt} \%$ and 0.10 to $2.84 \mathrm{wt} \%$, respectively. Minor components include $\mathrm{Hg}, \mathrm{Cd}, \mathrm{Pb}, \mathrm{Ni}, \mathrm{Co}$, and $\mathrm{Se}$ at 0.04 to $2.43 \mathrm{wt} \%, 0.03$ to 0.21 wt $\%, 0.04$ to 3.75 wt $\%, 0.01$ to 0.03 wt $\%, 0.01$ to 0.03 wt $\%$, and 0.04 to 0.07 wt \%; respectively (Table 2 ).

Pyrargyrite grains contain 58.34 to 71.20 wt \% Ag, 15.69 to 25.55 wt \% Sb, and 13.12 to $16.87 \mathrm{wt} \% \mathrm{~S}$. Copper content is commonly below its limit of detection. Polybasite-which occurs as anhedral crystals of varying size $(<0.01 \mathrm{~mm})$ or inclusions in, or grains adjacent to, freibergite, pyrargyrite, and galena (Figure 4B,E)—show silver contents between 70.2 and $74.8 \mathrm{wt} \%$; $\mathrm{Cu}$ and $\mathrm{Sb}$ are in the range of 3.88 to $5.78 \mathrm{wt} \%$ and 8.8 to $10.3 \mathrm{wt} \%$, respectively. Abundances of As are very low with most concentrations near detection limits. Acanthite (Figure 4D) exhibits highly variable Ag and S contents ranging from 85.06 to 91.89 wt \% and 6.65 to $13.49 \mathrm{wt} \%$, respectively (Table 2). Accessory Ag-bearing minerals include polybasite, argentite, and argentiferous galena, all of which occur as submicroscopic grains within major sulfides and sulfosalts.

In addition to the argentiferous-bearing sulfide and sulfosalt minerals, the Igoudrane ore is commonly accompanied by higher amounts of galena, sphalerite, chalcopyrite, pyrite, and arsenopyrite. Representative electron microprobe analyses of these base metal sulfides indicate homogenous compositions close to their ideal formula (Table 2).

\subsection{Trace Element and REE $+Y$ Compositions of Hydrothermal Calcite and Fluorite}

The composition of hydrothermal calcite is highly variable (Table 3). This mineral shows elevated concentrations of lanthanides and yttrium (REE+Y), ranging on average from 5.3 to $824.7 \mathrm{ppm}$, with ore-related calcite samples (Ca-1) from the main argentiferous stage being the most enriched in these elements ( $\Sigma \mathrm{REE}+\mathrm{Y}=337$ to $825 \mathrm{ppm}, n=7)$. In contrast, calcite from the late-stage base metal stage (Ca-2) exhibits the lowest levels of $\Sigma$ REE $+Y$, averaging $5 \mathrm{ppm}(n=4$, Table 3$)$. Strontium contents are less variable and range from 85 to $448 \mathrm{ppm}$, with Ca-2 having on average the highest values of $327 \mathrm{ppm}$.

The contents of $\mathrm{U}, \mathrm{Th}$, and $\mathrm{Ba}$ - in contrast-are very low, commonly close or below detection limits of around $0.02 \mathrm{ppm}$. Compared to Ca-1, fluorite samples show lower $\mathrm{REE}+\mathrm{Y}$ concentrations ( $\Sigma \mathrm{REE}+\mathrm{Y}=89.2 \mathrm{ppm}, n=3)$ which are in turn one order of magnitude higher than those of Ca-2 (Figure 6D). The LA-ICPMS data for calcite and fluorite indicate an overall increase in $\Sigma R E E+Y$ concentration with advanced paragenetic sequence. The $\mathrm{Y} / \mathrm{Ho}$ ratios for Ca-1 are near-chondritic to slightly sub-chondritic [21-29]; those for fluorite and Ca-2 are however clearly non chondritic exhibiting mean values of 70.5 and 40.6 , respectively (Table 3 ). 
Table 3. LA-ICPMS major and trace-element compositions of hydrothermal calcite and fluorite from the Igoudrane silver-rich $\pm \mathrm{Pb}-\mathrm{Zn}$ deposit.

\begin{tabular}{|c|c|c|c|c|c|c|c|c|c|}
\hline Sample No. & IG-09 & IG-22 & IG-46 & IG-16 & IG-22 & IG-48 & IG-213 & IG-100 $(n=4)$ & IF-120 $(n=3)$ \\
\hline Mineral & \multicolumn{7}{|c|}{ Ore-Related Calcite (Ca-1) } & $\begin{array}{c}\text { Late StageCalcites } \\
(\mathrm{Ca}-2)\end{array}$ & Fluorites \\
\hline \multicolumn{10}{|l|}{$\begin{array}{l}\text { Major elements } \\
\text { (wt. \%) }\end{array}$} \\
\hline $\mathrm{CaO}$ & 54.59 & 55.46 & 55.14 & 54.04 & 57.59 & 57.49 & 57.76 & 50.64 & 70.31 \\
\hline $\mathrm{MgO}$ & 0.02 & 0.01 & 0.02 & 0.04 & 0.05 & 0.06 & 0.04 & 3.23 & 0.27 \\
\hline $\mathrm{FeO}$ & 0.18 & 0.06 & 0.01 & 0.28 & 0.14 & 0.22 & 0.19 & 2.12 & 0.06 \\
\hline $\mathrm{MnO}$ & 1.31 & 0.48 & 0.76 & 1.38 & 1.03 & 1.11 & 1.82 & 0.20 & 0.07 \\
\hline \multicolumn{10}{|c|}{ Trace elements (ppm) } \\
\hline $\mathrm{Sr}$ & 188.85 & 147.93 & 448.25 & 94.25 & 134.00 & 85.00 & 132.00 & 326.53 & 30.33 \\
\hline $\mathrm{Ba}$ & 0.59 & 0.62 & 0.62 & 1.09 & 6.00 & 5.00 & 8.00 & 4.25 & 4.33 \\
\hline $\mathrm{La}$ & 44.38 & 14.38 & 19.93 & 80.70 & 23.10 & 191.00 & 37.20 & 0.54 & 5.70 \\
\hline $\mathrm{Ce}$ & 125.60 & 44.62 & 44.38 & 159.12 & 66.10 & 352.00 & 105.00 & 0.96 & 12.20 \\
\hline $\mathrm{Pr}$ & 17.22 & 6.76 & 7.50 & 16.52 & 9.09 & 34.90 & 14.20 & 0.13 & 1.57 \\
\hline $\mathrm{Nd}$ & 76.65 & 31.02 & 51.32 & 58.64 & 40.10 & 117.00 & 60.90 & 0.66 & 6.93 \\
\hline $\mathrm{Sm}$ & 21.89 & 10.07 & 17.53 & 10.81 & 11.70 & 18.50 & 16.60 & 0.15 & 2.10 \\
\hline $\mathrm{Eu}$ & 1.76 & 1.54 & 7.73 & 1.50 & 1.30 & 3.81 & 1.85 & 0.05 & 0.40 \\
\hline $\mathrm{Gd}$ & 26.35 & 12.12 & 27.18 & 9.55 & 12.30 & 13.50 & 16.80 & 0.13 & 3.10 \\
\hline $\mathrm{Tb}$ & 5.59 & 2.34 & 3.43 & 1.71 & 2.70 & 2.10 & 3.10 & 0.03 & 0.53 \\
\hline Dy & 45.14 & 17.98 & 21.00 & 10.20 & 19.20 & 11.50 & 22.00 & 0.16 & 3.17 \\
\hline$Y$ & 323.46 & 162.62 & 187.02 & 60.65 & 143.00 & 67.00 & 112.00 & 2.12 & 49.33 \\
\hline Ho & 10.68 & 4.43 & 4.59 & 1.95 & 4.40 & 2.00 & 4.50 & 0.05 & 0.70 \\
\hline $\mathrm{Er}$ & 33.87 & 14.05 & 12.32 & 5.49 & 14.70 & 5.60 & 13.50 & 0.15 & 1.87 \\
\hline $\mathrm{Tm}$ & 4.92 & 1.97 & 1.35 & 0.75 & 2.32 & 0.71 & 2.11 & 0.02 & 0.23 \\
\hline $\mathrm{Yb}$ & 30.80 & 11.93 & 7.12 & 4.74 & 15.70 & 4.50 & 16.90 & 0.13 & 1.17 \\
\hline $\mathrm{Lu}$ & 3.96 & 1.54 & 0.96 & 0.68 & 2.30 & 0.62 & 2.48 & 0.02 & 0.19 \\
\hline$\sum R E Y$ & 772.26 & 337.37 & 413.35 & 423.01 & 368.01 & 824.74 & 429.14 & 5.29 & 89.19 \\
\hline $\mathrm{Th}$ & 0.01 & $<0.01$ & n.d & 0.03 & n.d & 0.20 & n.d & 0.01 & 0.10 \\
\hline $\mathrm{U}$ & $<0.01$ & 0.01 & $<0.01$ & $<0.01$ & n.d & n.d & n.d & 0.32 & n.d \\
\hline $\mathrm{La} / \mathrm{Lu}$ & 11.22 & 9.31 & 20.67 & 118.10 & 10.04 & 308.06 & 15.00 & 26.84 & 30.00 \\
\hline $\mathrm{Y} / \mathrm{Ho}$ & 30.29 & 36.72 & 40.73 & 31.08 & 32.50 & 33.50 & 24.89 & 40.56 & 70.48 \\
\hline $\mathrm{Sm} / \mathrm{Yb}$ & 0.71 & 0.84 & 2.46 & 2.28 & 0.75 & 4.11 & 0.98 & 1.16 & 1.80 \\
\hline$(\mathrm{La} / \mathrm{Lu})_{\mathrm{CN}}$ & 1.20 & 1.00 & 2.22 & 11.28 & 1.08 & 33.02 & 1.61 & 2.88 & 3.22 \\
\hline$(\mathrm{La} / \mathrm{Sm})_{\mathrm{CN}}$ & 1.31 & 0.92 & 0.73 & 4.43 & 1.27 & 6.67 & 1.45 & 2.38 & 1.75 \\
\hline$(\mathrm{La} / \mathrm{Yb})_{\mathrm{CN}}$ & 1.03 & 0.86 & 2.01 & 10.89 & 1.06 & 30.45 & 1.58 & 3.07 & 3.50 \\
\hline$(\mathrm{Gd} / \mathrm{Lu})_{\mathrm{CN}}$ & 0.82 & 0.97 & 3.48 & 1.77 & 0.66 & 2.69 & 0.84 & 0.82 & 2.02 \\
\hline$(\mathrm{Tb} / \mathrm{Yb})_{\mathrm{CN}}$ & 0.83 & 0.89 & 2.19 & 1.67 & 0.78 & 2.12 & 0.83 & 1.21 & 2.08 \\
\hline$\left(\mathrm{Eu} / \mathrm{Eu}^{*}\right)_{\mathrm{CN}}$ & 0.22 & 0.43 & 1.08 & 0.45 & 0.33 & 0.74 & 0.34 & 1.01 & 0.48 \\
\hline$\left(\mathrm{Y} / \mathrm{Y}^{*}\right)_{\mathrm{CN}}$ & 1.13 & 1.39 & 1.45 & 1.05 & 1.19 & 1.07 & 0.86 & 1.76 & 2.53 \\
\hline$\left(\mathrm{Ce} / \mathrm{Ce}^{*}\right)_{\mathrm{CN}}$ & 1.11 & 1.11 & 0.89 & 1.07 & 1.12 & 1.06 & 1.12 & 0.88 & 1.00 \\
\hline
\end{tabular}

Abbreviations: $n=$ Number of analyses.

\subsection{Fluid Inclusion Microthermometry}

Microthermometric measurements were performed on ore-related quartz and calcite (Ca-1) from the main Ag-bearing stage and late-stage sphalerite wafers. In all of the selected samples, the fluid inclusion assemblages (FIAs) include primary FIs, either isolated or distributed along growth zones, as well as pseudosecondary FIs trapped along fracture planes. Two types of FIs are distinguished: (1) rare single-phase, vapor-rich FIs without any observable liquid phase (Type 1) making up less than $5 \mathrm{vol} \%$ of the measured inclusions; and (2) undersaturated, brine-bearing, two-phase FIs (Type 2) (Figure 7). Type 1 FIs have a median diameter up to $50 \mu \mathrm{m}$ and have ovoid shapes. Type 2 are much larger, irregularly shaped FIs with a median diameter of $150 \mu \mathrm{m}$. Based on visually estimated liquid to vapor ratios, the type 2 aqueous-bearing FIs exhibits relatively uniform ratios of 0.6 to 0.8 . Data of thermometric and salinity measurements are summarized in Table 4 and plotted in Figure 8. Only primary FIs were measured, according to the criteria of [62]. Type 1 vapor-rich FIs are rare, representing less than $5 \mathrm{vol} \%$ of the total measured inclusions. The type 1 melting temperatures of gas $\left(\mathrm{T}_{\mathrm{mgas}}\right)$ are around -58 to $-65^{\circ} \mathrm{C}$. This temperature range is slightly lower than the triple point for pure $\mathrm{CO}_{2}$, suggesting the presence of minor amounts of $\mathrm{H}_{2} \mathrm{O}$ and possibly other components such as $\mathrm{N}_{2}$ and $\mathrm{CH}_{4}$. The optical refraction of the calcite and low vapor density of the contained FIs preclude observation of any reliable phase variation or collection of Raman spectra. Homogenization temperatures $\left(T_{h}\right)$ of the type 
2 FIs trapped in quartz $(n=6)$ and sphalerite $(n=6)$ range from 195 to $218^{\circ} \mathrm{C}$ and from 135 to $151^{\circ} \mathrm{C}$, respectively. The melting temperatures of ice $\left(\mathrm{T}_{\mathrm{mi}}\right)$ values are comparable, varying from -5.0 to $-2.1^{\circ} \mathrm{C}$ and from -6.8 to $-3.6^{\circ} \mathrm{C}$, respectively. The $\mathrm{NaCl}$-equivalent salinity, calculated using an equation after [63], ranges from 3.5 to $7.9 \mathrm{wt} \%$ in quartz and 9.5 to $10.2 \mathrm{wt} \%$ in sphalerite (Figure $8 \mathrm{~B}$ ). In both minerals, the distribution of $\mathrm{T}_{\mathrm{h}}$ and $\mathrm{T}_{\mathrm{mi}}$ values is unimodal. The $T_{h}$ values of the FIs in calcite $(n=217)$ range from 150 to $225^{\circ} \mathrm{C}$, with a Gaussian around a peak at $180{ }^{\circ} \mathrm{C}$ (Figure 9A). A high-relief phase identified as hydrohalite melted between -29.2 and $-21.3^{\circ} \mathrm{C}$, with $\mathrm{T}_{\mathrm{mi}}$ values from -20.8 to $12.0^{\circ} \mathrm{C}$. The weight percent $\mathrm{NaCl}$ equivalent and total $\left(\mathrm{NaCl}+\mathrm{CaCl}_{2}\right)$ salinities, calculated using the equation of [64], vary from 5.5 to $19.1 \mathrm{wt} \%$ and 9.5 to $28.0 \mathrm{wt} \%$, respectively. $\mathrm{NaCl}$ and $\mathrm{CaCl}_{2}$ salinities show different distributions: whilst weight percent equivalent $\mathrm{CaCl}_{2}$ values display a well-defined Gaussian distribution with a maximum peak at 6 equiv. wt $\%$ $\mathrm{CaCl}_{2}, \mathrm{NaCl}$ peak shows a modal variance but is positively skewed (Figure $9 \mathrm{~B}$ ). $\mathrm{NaCl}$ and $\mathrm{CaCl}_{2}$ evolutions are therefore not correlated and seems to be driven by different geological processes. Total salinity $\left(\mathrm{NaCl}+\mathrm{CaCl}_{2}\right)$ shows a more complex multi-modal distribution with four peaks: two well-defined populations have maxima at 20 and $25 \mathrm{wt} \%$; the two other peaks at 12 and $15 \mathrm{wt} \%$, have low maxima ( $n=9$ inclusions) and could be included in the tail of the main peak at $20 \mathrm{wt} \%$ ( $n=50$ inclusions) (Figure $9 \mathrm{~B})$.
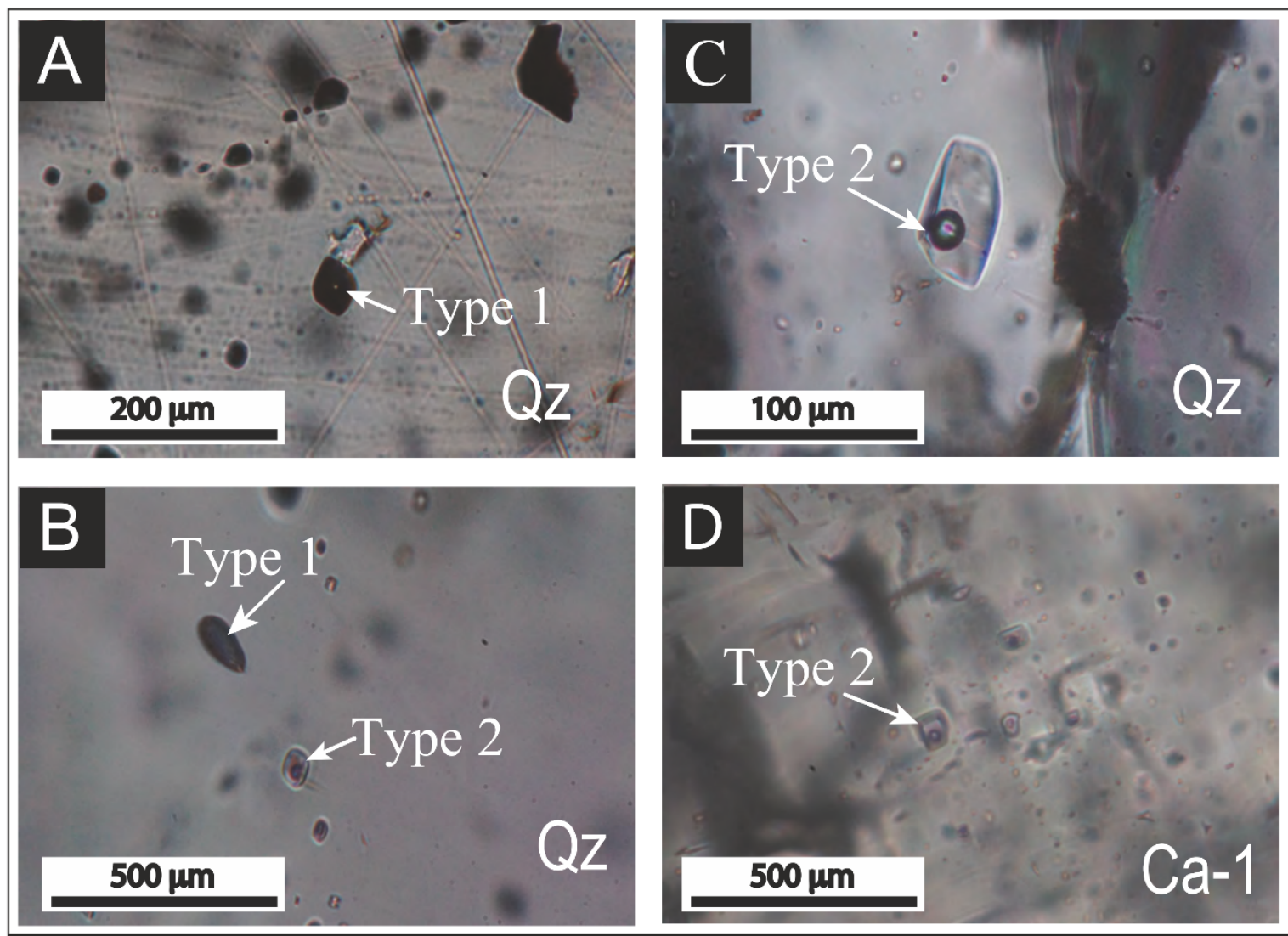

Figure 7. Representative photomicrographs in plane polarized light of doubly polished thick wafers showing selected petrographic relationships and types of fluid inclusions hosted in various generations of ore-related quartz and calcite, and late-stage sphalerite from the Igoudrane silver-rich $\pm \mathrm{Pb}-\mathrm{Zn}$ deposit. All photomicrographs were taken at room temperature. (A) Type I monophase vapor-rich inclusion consisting of pure vapor $\left(\mathrm{CO}_{2}\right)$ in stage 1 quartz. (B) Coexistence of type 1 monophase vapor-rich inclusion and type 2 biphasic aqueous fluid inclusion in stage 1 quartz. (C) Close up of a type 2 biphasic aqueous-bearing fluid inclusion. (D) Type 2 biphasic aqueous bearing fluid inclusion with negative crystal shape in stage 2 calcite. 
Table 4. Summary of microthermometric data of fluid inclusions from different stages in the the Igoudrane silver-rich $\pm \mathrm{Pb}-\mathrm{Zn}$ deposit.

\begin{tabular}{|c|c|c|c|c|c|c|c|c|c|c|c|}
\hline Sample No. & Stage/Sub-Stage & Mineral & Inclusion Type & Number & $\mathrm{T}_{\text {mgas }}\left({ }^{\circ} \mathrm{C}\right)$ & $\mathrm{T}_{\mathrm{mhh}}\left({ }^{\circ} \mathrm{C}\right)$ & $\mathrm{T}_{\text {mice }}\left({ }^{\circ} \mathrm{C}\right)$ & $\mathrm{T}_{\mathrm{h}}\left({ }^{\circ} \mathrm{C}\right)$ & $\begin{array}{l}\mathrm{NaCl}(\mathrm{wt} \% \\
\mathrm{NaCl}_{\text {eqv }} \text { ) }\end{array}$ & $\begin{array}{c}\mathrm{CaCl}_{2}(\mathrm{wt} \% \\
\left.\mathrm{CaCl}_{2 \text { eqv }}\right)\end{array}$ & $\begin{array}{c}\text { Total Salt (wt } \\
\% \mathrm{NaCl}^{+} \\
\mathrm{CaCl}_{2} \text { eqv) }\end{array}$ \\
\hline \multirow{2}{*}{ Ig-3 } & \multirow{2}{*}{ II.1 } & \multirow{2}{*}{ Calcite } & Type 1 & 8 & {$[-64.9$ to -58.4$]$} & - & - & - & - & - & - \\
\hline & & & Type 2 & 38 & - & {$\left[\begin{array}{l}{[-26.0 \text { to }} \\
-21.3]\end{array}\right.$} & {$[-18.0$ to 12.0$]$} & [218 to 265$]$ & [9.7 to 15.2 ] & [4.6 to 9.6] & [15.0 to 25.3 ] \\
\hline \multirow{2}{*}{$\operatorname{Ig}-4$} & \multirow{2}{*}{ II.1 } & \multirow{2}{*}{ Calcite } & Type 1 & - & - & - & - & - & - & - & - \\
\hline & & & Type 2 & 39 & - & $\begin{array}{c}{[-27.0 \text { to }} \\
-21.8]\end{array}$ & {$\left[\begin{array}{c}-17.9 \text { to } \\
-6.0]\end{array}\right.$} & [150 to 218 ] & [6.1 to 17.8 ] & [1.2 to 10.3 ] & [9.5 to 20.3 ] \\
\hline \multirow{2}{*}{ Ig-5 } & \multirow{2}{*}{ II.1 } & \multirow{2}{*}{ Calcite } & Type 1 & - & - & {$[.0]$} & $-0.0]$ & . & . & - & - \\
\hline & & & Type 2 & 25 & - & $\begin{array}{c}{[-29.0 \text { to }} \\
-23.0]\end{array}$ & {$\left[\begin{array}{c}-16.5 \text { to } \\
-11.0]\end{array}\right.$} & [159 to 193$]$ & [9.9 to 14.9 ] & [4.5 to 5.9] & [14.9 to 28.0] \\
\hline Ig-6 & II.1 & Calcite & Type 2 & 25 & - & $\begin{array}{c}{[-28.6 \text { to }} \\
-22.6]\end{array}$ & {$\left[\begin{array}{c}-20.8 \text { to } \\
-13.6]\end{array}\right.$} & [173 to 187$]$ & [5.5 to 17.4$]$ & [4.0 to 18.2$]$ & [17.2 to 25.6$]$ \\
\hline \multirow{2}{*}{ Ig-7 } & \multirow{2}{*}{ II.1 } & \multirow{2}{*}{ Calcite } & Type 1 & - & - & - & ! & - & - & - & - \\
\hline & & & Type 2 & 40 & - & $\begin{array}{c}{[-228.0 \text { to }} \\
22.0]\end{array}$ & [ -19.8 to 19.0$]$ & [163 to 191] & [8.0 to 19.1] & [2.3 to 12.8 ] & [12.9 to 21.7] \\
\hline \multirow{2}{*}{ Ig-8 } & \multirow{2}{*}{ II.1 } & \multirow{2}{*}{ Calcite } & Type 1 & - & - & 20.0 & - & - & - & - & - \\
\hline & & & Type 2 & 33 & - & $\begin{array}{c}{[-29.2 \text { to }} \\
-21.8]\end{array}$ & {$[-19.2$ to 12.5$]$} & [166 to 225$]$ & [6.2 to 18.2 ] & [1.7 to 12.4$]$ & [16.3 to 21.2] \\
\hline \multirow{2}{*}{ Ig-9 } & \multirow{2}{*}{ II. 1} & \multirow{2}{*}{ Calcite } & Type 1 & - & - & {$[.0]$} & - & - & - & - & - \\
\hline & & & Type 2 & 17 & . & $\begin{array}{c}{[-25.1 \text { to }} \\
-22.7]\end{array}$ & $\begin{array}{c}{[-19.9 \text { to }} \\
-13.0]\end{array}$ & [170 to 189$]$ & [11.8 to 14.9$]$ & [3.3 to 9.2$]$ & [16.7 to 21.5] \\
\hline Ig-5 & I & Quartz & $\begin{array}{l}\text { Type } 1 \\
\text { Type } 2\end{array}$ & 7 & {$[-58.1$ to 66.7$]$} & . & !. & : & : & : & : \\
\hline Ig-5 & I & Quartz & $\begin{array}{l}\text { Type } 1 \\
\text { Type } 2\end{array}$ & 6 & 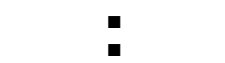 & 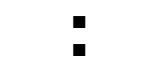 & {$[-5.0$ to -2.1$]$} & [195 to 218] & [3.5 to 7.9$]$ & 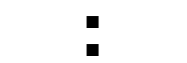 & [3.5 to 7.9$]$ \\
\hline
\end{tabular}




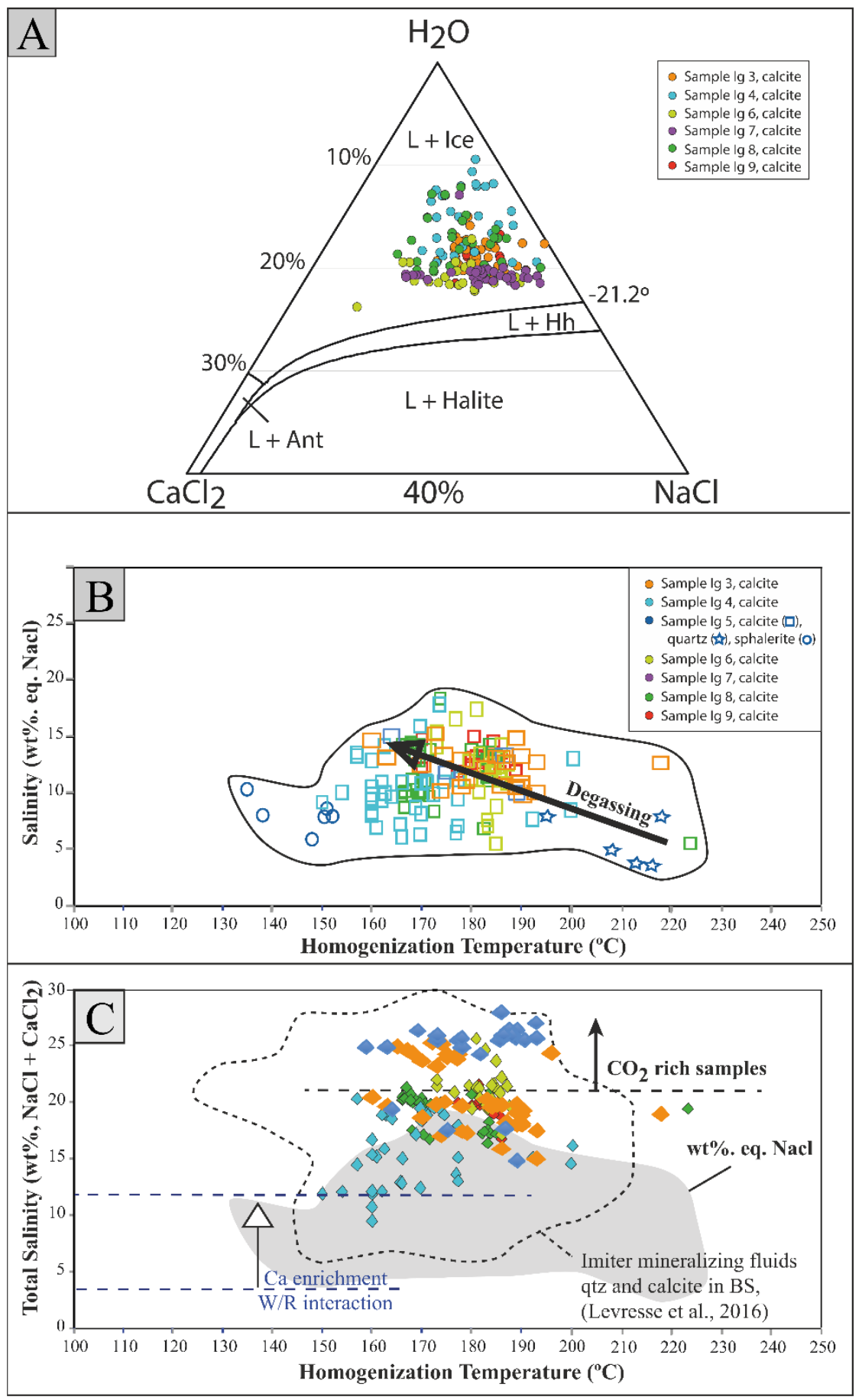

Figure 8. Plots of microthermometric data for fluid inclusions trapped in ore-related quartz and calcite, and late-stage sphalerite from the Igoudrane silver-rich $\pm \mathrm{Pb}-\mathrm{Zn}$ deposit. (A) Ternary vaporsaturated liquidus phase diagram of [64] showing the distribution of $\mathrm{H}_{2} \mathrm{O}-\mathrm{NaCl}-\mathrm{CaCl}_{2}$ ratios of primary fluid inclusions. (B) Homogenization temperature versus $\mathrm{NaCl}$ salinity plot of primary and pseudosecondary fluid inclusions. The arrow indicates the presumed degassing trend that would have been responsible for the increase of salinity with decreasing temperature. Symbol size is larger than the $2 \sigma$ uncertainty. (C) Homogenization temperature versus total $\mathrm{NaCl}+\mathrm{CaCl}_{2}$ salinity plot of primary and pseudosecondary fluid inclusions showing the effect of fluid-rock interaction. The legend is the same as for (B). Abbreviations: Ant = antarcticite; $\mathrm{Hh}=$ hydrohalite; $\mathrm{L}=$ liquid. 

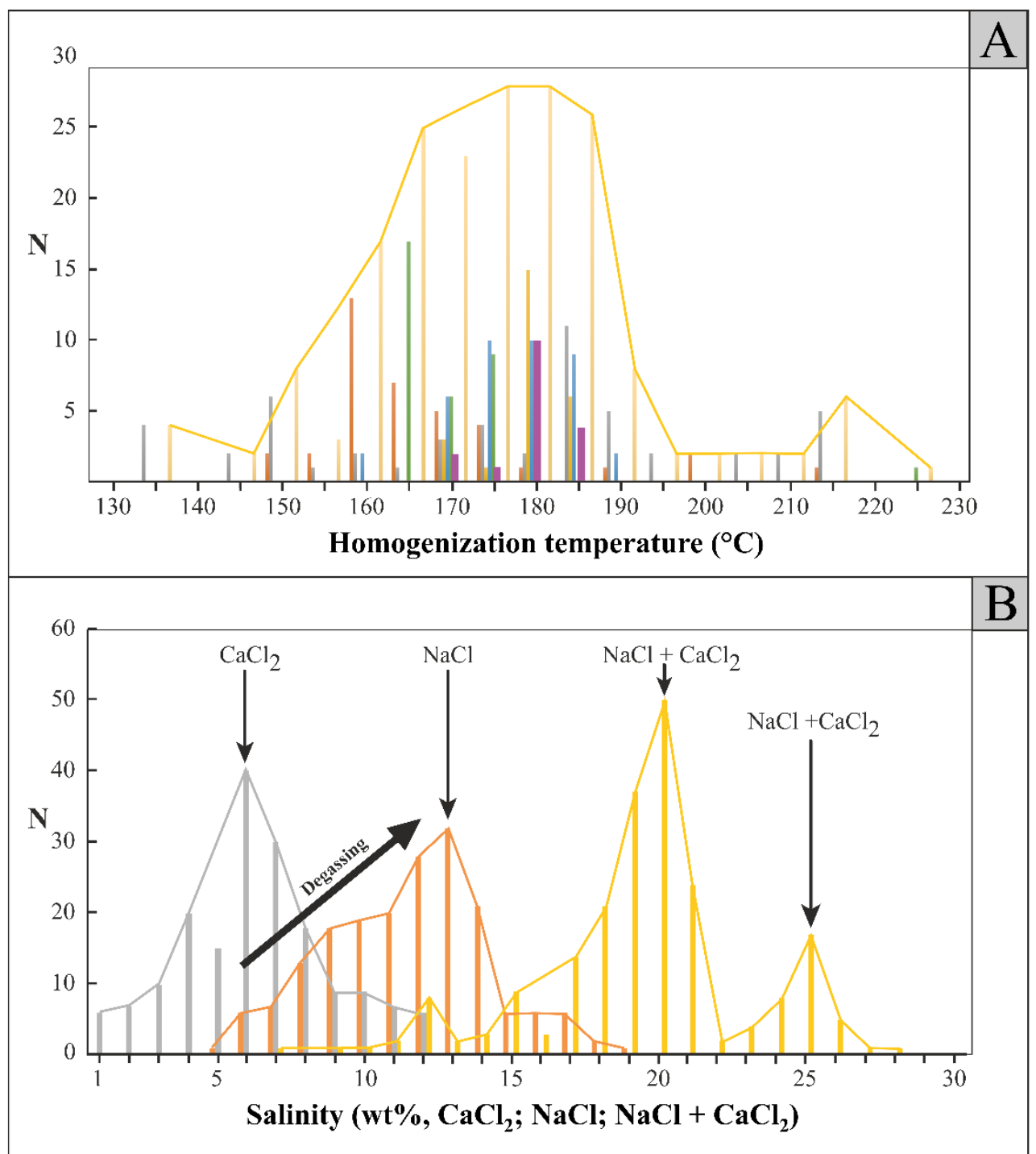

Figure 9. Histograms showing (A) the gaussian distribution of homogenization temperatures, and (B) the evolution of salinity from microthemometric data of ore-related quartz and calcite, and late-stage sphalerite from the Igoudrane silver-rich $\pm \mathrm{Pb}-\mathrm{Zn}$ deposit.

Results of the decrepitation experiments on three representative calcite samples display an approximate unimodal distribution pattern with a maximum peak of ca. $440{ }^{\circ} \mathrm{C}$ (Figure 10). One sample has a bimodal distribution with two maxima at ca. $440{ }^{\circ} \mathrm{C}$ and $550{ }^{\circ} \mathrm{C}$. Calcite cements from the higher-grade Ag-rich samples are characterized by higher FIs decrepitation counts per $10 \mathrm{~s}$ and a more-defined peak at $440{ }^{\circ} \mathrm{C}$. 


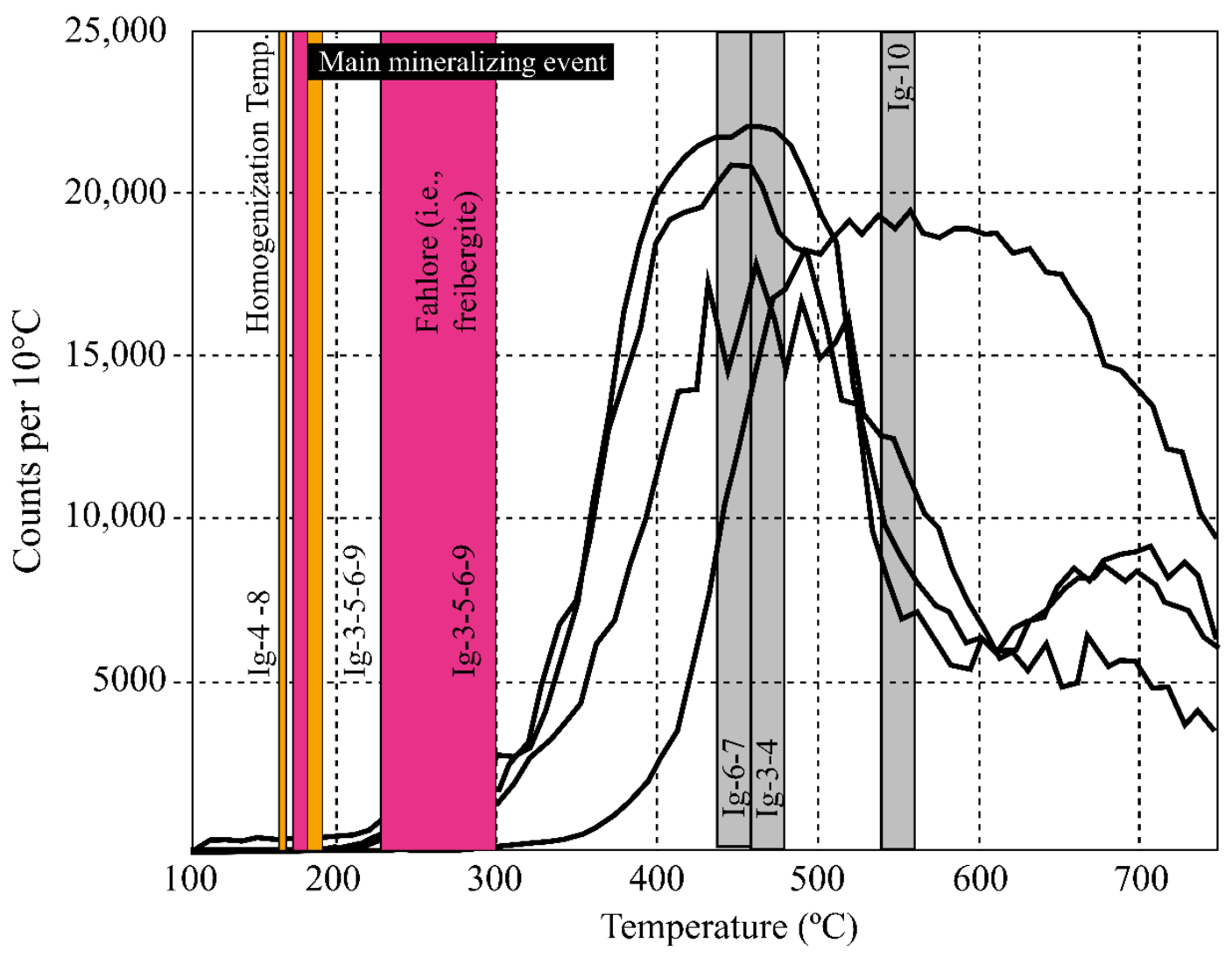

Figure 10. Fluid inclusion decrepitation temperatures for ore-related quartz and calcite from the main silver-rich mineralization stage at Igoudrane silver-rich $\pm \mathrm{Pb}-\mathrm{Zn}$ deposit compared with mean homogenization temperatures of the studied fluid inclusions (in orange) and equilibrium temperatures from fahlore thermochemistry (in red).

\subsection{Carbon and Oxygen Isotopes}

Carbon and oxygen isotope compositions of the main silver stage Ca-1 and late-stage base metal Ca-2 are reported in Table 5 and Figure 11. A total of 31 analyses were performed on monomineralic fractions, representing all observed petrographic variations within the deposit. Overall, Ca-1 displays $\mathrm{C}$ isotope compositions that fall within a narrower $\delta^{13} \mathrm{C}_{\mathrm{V}-\mathrm{PDB}}$ range ( -11.6 to $-8.3 \%$ o $)$, but extend to much higher $\delta^{18} \mathrm{O}_{\mathrm{V}-\mathrm{SMOW}}$ values $(9.0$ to $18.7 \%$ ). Conversely, the $\delta^{13} \mathrm{C}_{\mathrm{V}-\mathrm{PDB}}$ and $\delta^{18} \mathrm{O}_{\mathrm{V}-\mathrm{SMOW}}$ values of Ca-2 show uniform higher isotopic ratios ranging from -4.1 to $-0.9 \%$ and 18.4 to $19.8 \%$, respectively.

Compared to marine carbonates of Neoproterozoic age [65,66], all Ca-1 and Ca-2 calcites are lower in $\delta^{18} \mathrm{O}_{\mathrm{V}-\mathrm{SMOW}}$ than Neoproterozoic marine carbonates, suggesting that mineralization involved elevated temperatures or isotopically light meteoric water. Of particular interest is the linear variation displayed by Ca-1 samples involving a shift of $8 \%$ in $\delta^{18} \mathrm{O}_{\mathrm{V}-\mathrm{SMOW}}$ values at almost constant $\delta^{13} \mathrm{C}_{\mathrm{V}-\mathrm{PDB}}$ ratios of $-9 \%$ (Figure 11). 
Table 5. Carbon, oxygen, and strontium isotope compositions of hydrothermal calcite from the Igoudrane silver-rich $\pm \mathrm{Pb}-\mathrm{Zn}$ deposit. Oxygen isotope compositions of the ore-forming fluids $\left(\delta^{18} \mathrm{O}_{\mathrm{fV}-\mathrm{SMOW}}\right)$ are calculated using the calcite- $\mathrm{H}_{2} \mathrm{O}$ fractionation factor of $[67,68]$.

\begin{tabular}{|c|c|c|c|c|c|}
\hline Sample No. & Mineral/Stage & $\mathcal{\delta}^{18} \mathrm{O}_{\text {V-SMOW }}(\%)$ & $\delta^{13} C_{\text {V-PDB }}(\%)$ & ${ }^{87} \mathrm{Sr} /{ }^{86} \mathrm{Sr} \pm 2 \sigma$ & $\begin{array}{l}\text { Calculated } \delta^{18} \mathrm{O}_{\text {fluid }} \\
\left(\% \text { ) at } 250{ }^{\circ} \mathrm{C}\right.\end{array}$ \\
\hline Ig-1 & Calcite (Ca-1) & 12.7 & -9.4 & - & 5.2 \\
\hline Ig-2 & Calcite (Ca-1) & 13.4 & -10.1 & - & 5.9 \\
\hline Ig-3 & Calcite (Ca-1) & 12.6 & -10.0 & - & 5.1 \\
\hline $\operatorname{Ig}-4$ & Calcite (Ca-1) & 13.2 & -11.4 & - & 5.7 \\
\hline $\operatorname{Ig}-5$ & Calcite (Ca-1) & 13.8 & -10.1 & - & 6.3 \\
\hline $\operatorname{Ig}-6$ & Calcite (Ca-1) & 13.1 & -8.7 & - & 5.6 \\
\hline Ig-7 & Calcite (Ca-1) & 13.0 & -9.8 & - & 5.5 \\
\hline $\operatorname{Ig}-8$ & Calcite (Ca-1) & 15.3 & -9.5 & $0.710198 \pm 0.000016$ & 7.8 \\
\hline Ig-9 & Calcite (Ca-1) & 9.0 & -9.5 & - & 1.5 \\
\hline $\operatorname{Ig}-10$ & Calcite (Ca-1) & 14.3 & -9.4 & - & 6.8 \\
\hline Ig-11 & Calcite (Ca-1) & 12.9 & -9.4 & $0.707657 \pm 0.000016$ & 5.4 \\
\hline Ig-12 & Calcite (Ca-1) & 16.8 & -9.4 & - & 9.3 \\
\hline $\operatorname{Ig}-13$ & Calcite (Ca-1) & 12.0 & -9.7 & - & 4.5 \\
\hline Ig-14 & Calcite (Ca-1) & 17.5 & -9.2 & - & 10.0 \\
\hline Ig-15 & Calcite (Ca-1) & 10.7 & -11.6 & - & 3.2 \\
\hline Ig-16 & Calcite (Ca-1) & 14.1 & -9.0 & - & 6.6 \\
\hline Ig-17 & Calcite (Ca-1) & 17.1 & -9.3 & - & 9.6 \\
\hline Ig-18 & Calcite (Ca-1) & 12.8 & -9.8 & - & 5.3 \\
\hline Ig-19 & Calcite (Ca-1) & 15.1 & -8.3 & - & 7.6 \\
\hline Ig-20 & Calcite (Ca-1) & 12.7 & -9.4 & - & 5.2 \\
\hline $\operatorname{Ig}-21$ & Calcite (Ca-1) & 13.4 & -9.0 & - & 5.9 \\
\hline Ig-22 & Calcite (Ca-1) & 17.1 & -8.8 & - & 9.6 \\
\hline Ig-23 & Calcite (Ca-1) & 12.5 & -9.5 & - & 5.0 \\
\hline Ig-24 & Calcite (Ca-1) & 13.1 & -9.6 & - & 5.6 \\
\hline $\operatorname{Ig}-25$ & Calcite (Ca-1) & 18.7 & -9.4 & - & 11.2 \\
\hline Ig-26 & Calcite (Ca-1) & 13.7 & -9.7 & - & 6.2 \\
\hline Ig-27 & Calcite (Ca-1) & 12.6 & -9.7 & - & 5.1 \\
\hline $\mathrm{Ig}-28$ & Calcite (Ca-2) & 19.7 & -0.9 & - & 12.2 \\
\hline Ig-29 & Calcite (Ca-2) & 18.4 & -2.6 & $0.708535 \pm 0.000014$ & 10.9 \\
\hline $\operatorname{Ig}-30$ & Calcite (Ca-2) & 19.8 & -2.3 & $0.710918 \pm 0.000012$ & 12.3 \\
\hline Ig-31 & Calcite (Ca-2) & 18.7 & -4.1 & - & 11.2 \\
\hline
\end{tabular}

\subsection{Strontium Isotopes}

Strontium isotope compositions were determined for four calcite separates (Ca-1 and $\mathrm{Ca}-2$ ) that span the sequence of mineral deposition (Table 5, Figure 12). Very low $\mathrm{Rb} / \mathrm{Sr}$ ratios in calcite imply that the measured ${ }^{87} \mathrm{Sr} /{ }^{86} \mathrm{Sr}$ values have not been affected significantly by ${ }^{87} \mathrm{Rb}$ decay and therefore provide a reasonable proxy to the initial ${ }^{87} \mathrm{Sr} /{ }^{86} \mathrm{Sr}$ values of parental fluids during calcite precipitation. Overall, ore-related calcite (Ca-1) and post-ore calcite (Ca-2) show highly variable and overlapping ${ }^{87} \mathrm{Sr} /{ }^{86} \mathrm{Sr}$ ratios ranging from 0.707657 to 0.710918 . Compared to Neoproterozoic seawater values of 0.7075 to 0.7070 [69], the ${ }^{87} \mathrm{Sr} /{ }^{86} \mathrm{Sr}$ ratios of Ca-1 and Ca-2 form two distinct groups, one of which plots within the field of Neoproterozoic seawater signature (Figure 12). 


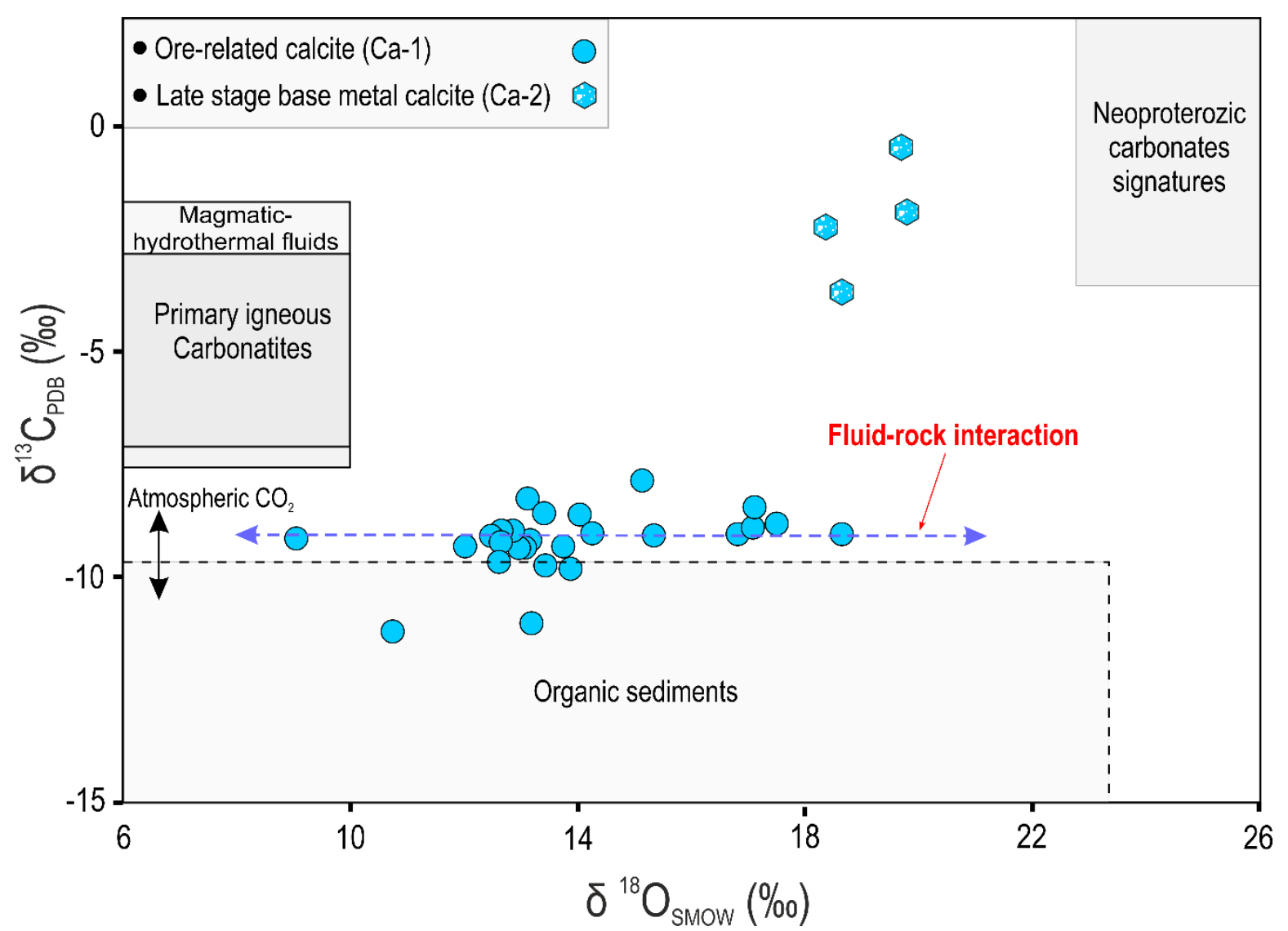

Figure 11. Carbon and oxygen isotope compositions, expressed as $\% \delta^{18} \mathrm{O}_{\mathrm{V}-\mathrm{SMOW}}$ and $\delta^{13} \mathrm{C}_{\mathrm{V}-\mathrm{PDB}}$ respectively, of bulk-rock calcite fractions from the Igoudrane silver-rich $\pm \mathrm{Pb}-\mathrm{Zn}$ deposit. Note that the data extend from the field for Neoproterozoic marine carbonates toward lighter oxygen and carbon compositions. The compositional fields of mantle and primary igneous carbonatites of [70,71], and Neoproterozoic marine carbonates of [66] are indicated for comparison. The horizontal trend indicates fluid-rock interaction. Symbol size is larger than the $2 \sigma$ uncertainty.

\section{Discussion}

Given the subaqueous geologic setting and the presence of large igneous rocks in the Igoudrane deposit, the two major fluids present were most likely seawater, or intraformational derivation (i.e., basinal brines) and magmatic-hydrothermal fluid. Moreover, the presence of sphalerite-galena-silver sulfosalts, and fahlore (i.e., tetrahedrite-tennantite series) together with variable amounts of chalcopyrite indicate a low to intermediate sulfidation state.

\subsection{Physicochemical Conditions and Sources of the Ore Fluids}

Hydrothermal fluid is a generic term for hot groundwaters that circulate within the Earth's crust without any further genetic connotation [72]. As a result, these fluids can be magmatically related or hot basinal brines, or a combination of both. Although the relative enrichment or depletion of individual elements varies for the different generations of Ca-1, fluorite, and Ca-2, the shapes of the REE+Y patterns for these minerals are broadly similar to those of the whole-rock samples with pronounced negative Eu anomalies (Figure 6D), indicating a common origin for the aforementioned minerals and the associated hosting rocks.

In the Igoudrane deposit, the measured $\mathrm{T}_{\mathrm{h}}$ and salinities of type 2 FIs range from 135 to $225^{\circ} \mathrm{C}$ and 3.5 to $28 \mathrm{wt} \%$ equiv. $\mathrm{NaCl}$. The few microthermometric data obtained from the type 1 vapor-rich FIs suggest a fluid mixture with dominant $\mathrm{CO}_{2}$, whereas type 2 FIs contain a significant $\mathrm{CO}_{2}$ concentration, in particular where in close spatial 
association with the type 1 FIs. Such low temperatures and high-salinity fluids have typically been interpreted as reflecting deposition from basinal brines [5,73]. Nonetheless, the mineralizing fluids in the Igoudrane deposit show evidence of a more heterogenous and complex chemical system. FIs in ore-related quartz and late-stage sphalerite are both characterized by salinities ranging from 3.5 to 10 equiv. wt \% NaCl. Data for the Ca-1 and Ca-2 samples show more complex fluid compositions in term of their corresponding $\mathrm{NaCl}+\mathrm{CaCl}_{2}$ salinities. The calculated salinities following the Oakes equation [64] show a wide range of variation (Figure $8 \mathrm{~B}$ ), where the higher $\mathrm{NaCl}$ content in the calcite seems to correlate with high $\mathrm{CO}_{2}$ and $\mathrm{Ag}$ contents (Figure $8 \mathrm{C}$ ). $\mathrm{CaCl}_{2}$ salinity is only observed in calcite, for which concentrations are likely to be derived from the host black shales at different ratios of water-rock interaction. Temperatures of the Igoudrane mineralizing system can be estimated based on combination of data from FIs microthermometry and decrepitation (Figure 10), and fahlore (i.e., freibergite) thermochemistry (Figure 13). Two distinct temperature-related populations are defined with both techniques. The main population which is represented by the Ag- and $\mathrm{CO}_{2}$-rich FIs (samples Ig-3-5-6-9) shows a $\mathrm{T}_{\mathrm{h}}$ range from 180 to $440{ }^{\circ} \mathrm{C}$ and fahlore equilibrium temperature range of 230 to $300^{\circ} \mathrm{C}$. Conversely, data from the paragenetically later event (samples Ig-4-8) display a $\mathrm{T}_{\mathrm{h}}$ range of 160 to $440{ }^{\circ} \mathrm{C}$ and fahlore equilibrium temperature below $200{ }^{\circ} \mathrm{C}$. The complexity of the Na-Ca rich fluid system does not allow an estimate of the P-T trapping conditions. However, with such high fluid densities, fluid compositions, and temperature ranges, the hydrothermal environment cannot have been shallow, pointing instead towards a deep-seated magmatic contribution. Further support for the involvement of a magmatic component is provided by the $\mathrm{Y} / \mathrm{Ho}$ and $\mathrm{La} / \mathrm{Ho}$ chondritic ratios (Table 3), which are chondritic being indistinguishable from those of mantle-derived rocks [74-77]. The nonchondritic values exhibited by the paragenetically late fluorite and Ca-2, however, mirror the compositions of calcite and fluorite precipitated from low- or medium-temperature aqueous systems [75].

\subsection{Evolution of the Ore-Forming Fluid and Ore Depositional Processes}

Assuming an overall average temperature of $250^{\circ} \mathrm{C}$ as inferred from fluid inclusion data and fahlore thermochemistry (Figure 13), the calculated oxygen isotope compositions of the ore-forming fluids $\left(\delta^{18} \mathrm{O}_{\mathrm{V}}^{\mathrm{f}} \mathrm{SMOW}\right)$ using the calcite- $\mathrm{H}_{2} \mathrm{O}$ fractionation factor of $[67,68]$ range from 1.2 to $12.3 \%$; most are between 5 and $10 \%$. Overall, these compositions overlap well with the range of typical magmatic values $(5.5-10.0 \%$; $[78,79])$. Some of the plotted data are shifted away from this signature, which indicates the involvement of fluids that are possibly meteoric in origin and/or extensive fluid/wall-rock interaction with the enclosing host rocks.

The trend toward higher $\delta^{18} \mathrm{O}$ values with advancing paragenetic sequence from early ore-related Ca- $1\left(\delta^{18} \mathrm{O}_{\mathrm{V} \text {-SMOW }}^{\mathrm{f}}=6.3 \pm 2.1 \%, n=27\right)$ to late Ca-2 $\left(\delta^{18} \mathrm{O}_{\mathrm{V}-\mathrm{SMOW}}^{\mathrm{f}}=11.6 \pm 0.7 \%\right.$, $n=4)$ which coincides with a roughly $100{ }^{\circ} \mathrm{C}$ decrease in the temperature of mineral deposition could be interpreted to reflect cooling/dilution of ore-forming fluids, or fluid mixing, or a combination of both. Further support for mixing of fluids is provided by the net decrease in Th with time from the main silver stage $\left(\mathrm{T}_{\mathrm{h}}=180 \pm 12{ }^{\circ} \mathrm{C}\right)$ to late base-metal stage $\left(\mathrm{T}_{\mathrm{h}}=146 \pm 7^{\circ} \mathrm{C}\right)$ coupled with the large variations in corresponding salinities that range from 3.4 to 19.1 equiv. wt \% $\mathrm{NaCl}$ (Figure 8B,C). 


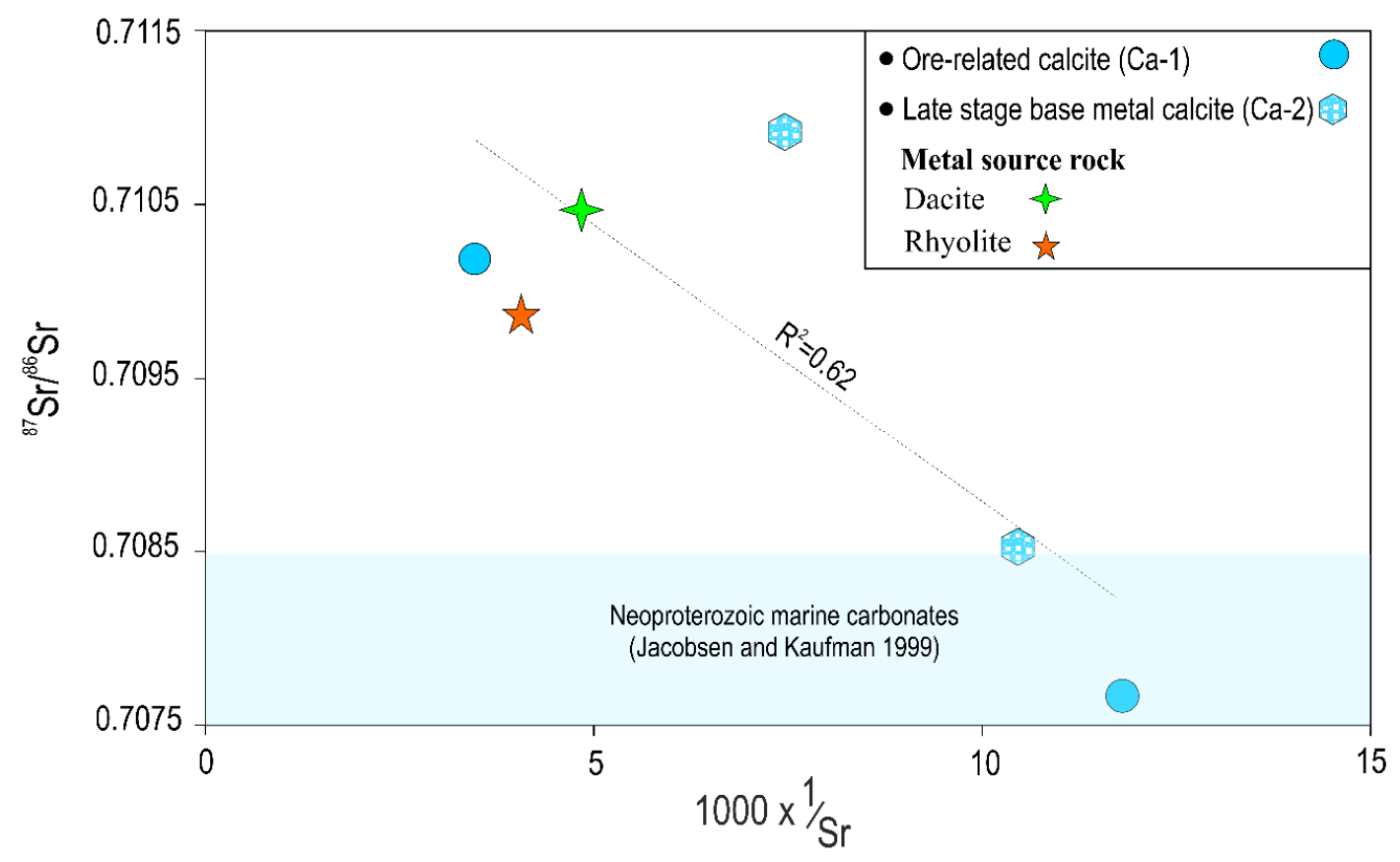

Figure 12. Geochemical plot of ${ }^{87} \mathrm{Sr} /{ }^{86} \mathrm{Sr}$ versus $1000 \times 1 / \mathrm{Sr}$ showing the isotopic compositions of ore-related hydrothermal calcite (Ca-1) and post-ore calcite (Ca-2) from Igoudrane silver-rich $\pm \mathrm{Pb}-\mathrm{Zn}$ deposit compared to those of potential rock sources (i.e., rhyolite, rhyodacite). Neoproterozoic marine carbonates compositional field is from [69]. ${ }^{87} \mathrm{Sr} /{ }^{86} \mathrm{Sr}$ isotopic ratios for rhyolite and dacite are from [50].

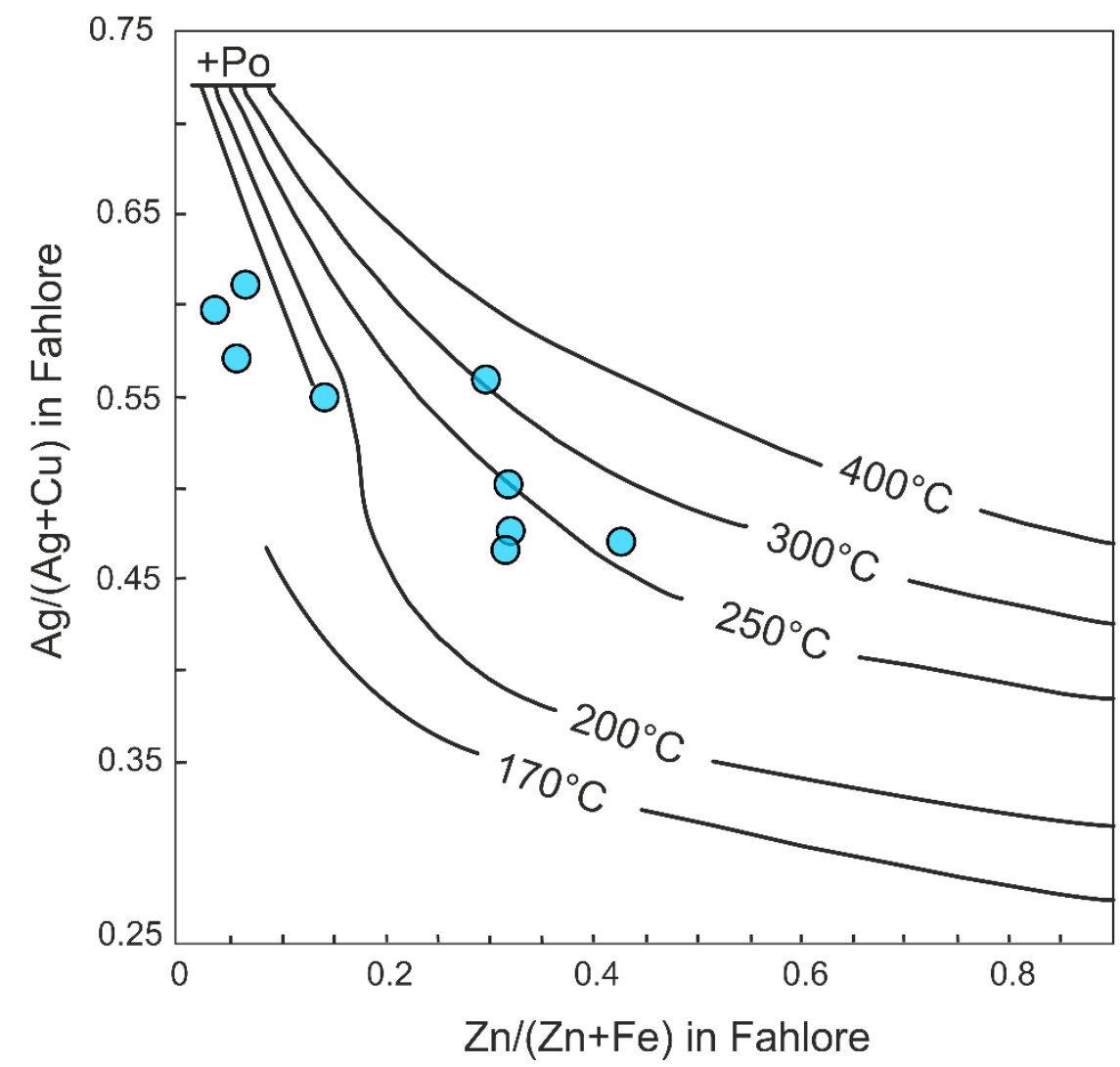

Figure 13. Average molar $\mathrm{Ag} /(\mathrm{Ag}+\mathrm{Cu})$ and $\mathrm{Zn} /(\mathrm{Zn}+\mathrm{Fe})$ plots for primary fahlore (i.e., freibergite) in the Igoudrane deposit. The isotherms which terminate at low $\mathrm{Zn} /(\mathrm{Zn}+\mathrm{Fe})$ and high $\mathrm{Ag} /(\mathrm{Ag}+\mathrm{Cu})$ ratios because of saturation with respect to pyrrhotite (Po) (reference $[80,81]$ ) are from [82]. 
This decrease in $T_{h}$ indicates that at least two fluid components (high-temperature, high-salinity end-members; and low-temperature, low-salinity end-members) were involved in the mineralizing process. The high-salinity end-member corresponds to magmaticderived halogen-bearing brine that exsolved from a high- $\delta{ }^{18} \mathrm{O}$ magmatic system, as suggested by the widespread development of brecciated ores and the coexistence of aqueous and $\mathrm{CO}_{2}$-bearing FIs. The low-temperature, low-salinity end-member corresponds to the influx of downward flowing heated meteoric water. Progressive incursion of meteoric water during the collapse of the hydrothermal system caused the gradual dilution of ore-forming fluid and reduced its temperature and salinity, resulting in deposition of the Igoudrane silver-rich ores. This interpretation is consistent with an apparent correlation between ${ }^{87} \mathrm{Sr} /{ }^{86} \mathrm{Sr}$ and $1 / \mathrm{Sr} \times 1000$ (Figure 12), suggesting that dissolved strontium can be derived either directly or indirectly from a mixture of the radiogenic felsic rocks (dacite and rhyolite) and associated Neoproterozoic marine carbonates. Additional support for a marine carbonate input is provided by some of the $\mathrm{C}$ and $\mathrm{O}$ isotopic compositions of Ca-2 that plot close to the marine carbonate field (Figure 11). Although possible, such fluid source, if any, remains minor as a marine origin for the carbon should result in $\delta^{13} \mathrm{C}$ value close to $0 \%[83,84]$. Accordingly, it is concluded that the major source of $\mathrm{Sr}$ and by inference accompanying metals was the Neoproterozoic igneous rocks.

In addition to fluid mixing and subsequent cooling/dilution, extensive fluid/wallrock interaction between mineralizing fluids and the country rocks seems to have exerted a strong control on mineral deposition as evidenced by the sub-horizontal scatter of $\delta^{13} C_{\mathrm{PDB}}$ ratios at constant value of $-10 \%$ (Figure 11). In fact, this trend is interpreted to reflect isotopic re-equilibration of the deeply sourced hydrothermal fluids that circulated through, and equilibrated with, the host rocks including the organic-rich black shales and the igneous counterparts. In this respect, modeling calculations performed by Levresse $[3,4]$ indicate that, at Imiter district, the host black shales contributed less than $10 \%$ to the osmium budget in the silver and base metal events.

In summary, the combined trace element geochemistry, petrographic and microthermometric analyses of fluid inclusions, and stable $(\mathrm{C}, \mathrm{O})$ and radiogenic $(\mathrm{Sr})$ isotope data indicate that deposition of the silver-rich $\pm \mathrm{Pb} \pm \mathrm{Zn}$ ores of Igoudrane deposit could have been achieved through three main mechanisms (or a combination of two or more of these), including: (1) fluid boiling-degassing; (2) fluid mixing and subsequent cooling/dilution; and (3) fluid-rock interactions along flow path.

\subsection{Geochemical Signature of Fluorite as a Proxy for Fluid Source and Evolution of the Mineralizing Fluids}

The presence of fluorite is of prime importance in constraining the origin of the mineralizing fluids and ore-forming processes involved in the genesis of the Igoudrane deposit. In fact, the occurrence of fluorite and carbonates (mainly calcite) along with the relatively high salinities and $\mathrm{CO}_{2}$ content of the vapor-rich and aqueous FIs indicate that the ore-forming fluid was saturated in $\mathrm{F}, \mathrm{Cl}$, and $\mathrm{CO}_{2}$. This highlights the importance of, $\mathrm{CO}_{2}$ and fluoro-chloro-complexing agents for lithophile element transport in ore formation. The capacity of halogen complexes for the transport of lithophile elements has been confirmed by experimental data [85-88].

The REE $+Y$ geochemistry of gangue minerals, including the early precipitating orerelated Ca-1 suite and the paragenetically later fluorite and post-ore Ca-2 suite, could provide additional constraints on the origin and evolution of the Igoudrane hydrothermal system. Although Ca-1 minerals contain $\Sigma \mathrm{REE}+\mathrm{Y}$ concentrations that are several orders of magnitude higher than those of the late fluorite and Ca-2 specimens, along with the associated igneous felsic rocks, the similarities between chondrite-normalized REE patterns of fluorite and those of the associated felsic rocks (i.e., flat, insignificant tetrad effect, and negative Eu anomalies) (Figure 6D) indicate that magma composition controls the composition of the fluorite and related silver mineralization, in agreement with the conclusions of Gagnon [89]. In the early stage, ore fluids contained relatively higher REE+Y concentrations. After the precipitation of $\mathrm{Ca}-1$ suite minerals, residual fluid was subse- 
quently depleted in REE $+\mathrm{Y}$, which resulted in lower concentrations in the later fluorite and subsequent post-ore Ca-2 specimens, consistent with experiments of [90] which show fast depletion of (REE/Ca)fluid due to strong REE consumption by growing Ca-1. Our REE data, however, do not exclude the possible involvement of a magmatic fluid that derived some of its metal content through extensive fluid-rock interaction with the host rocks as shown above. Moreover, the prominent positive $\mathrm{Y}$ anomaly exhibited by fluorite and Ca-2 minerals indicate strong F complexing [91] and a relatively distant source of fluids from the Igoudrane mine site.

These results demonstrate a close chronological correspondence of magmatism and silver-rich mineralization in Igoudrane deposit. Based on this relationship, we infer that that the hydrothermal system which produced the Igoudrane deposit was likely driven by magmatism, and not a product of basin-derived fluids (i.e., basinal brines). Igneous rocks are widespread in the study area-spanning a time period of $\sim 25$ m.y., from approximately 565 to $543 \mathrm{Ma}$. Accordingly, we could not rely the genesis of Igoudrane mineralization to a specific magmatic event because of the lack of robust age determination on mineralization. Moreover, we cannot rule out the possibility that the hydrothermal system was periodically active over this time period, and even younger reactivations of hydrothermal activity could have occurred during the Triassic as revealed by the ${ }^{40} \mathrm{Ar} /{ }^{39} \mathrm{Ar}$ age dating of adularia, which yielded a well-defined age of $254.7 \pm 3.2 \mathrm{Ma}$ [92]. Given the data currently available additional sampling and analysis would be necessary to fully demystify the origin of the silver-rich mineralization at Igoudrane deposit and by extension the entire Imiter district.

\section{Concluding Remarks}

This study reports the first attempt that combines underground mapping of the Igoudrane silver-rich deposit, drill core examination, petrographic, electron microprobe, and LA-ICP-MS analyses in conjunction with fluid inclusion microthermometry and stable $(\mathrm{C}, \mathrm{O})$ and radiogenic $(\mathrm{Sr})$ isotopic data to constrain the origin and evolution of the mineralizing fluids and depositional processes that led to the precipitation of silver mineralization in this deposit. New findings and conclusions are as follows:

1. Economic mineralization consists mainly of open-space fillings in veins, veinlet intergranular voids, stockwork, and breccias with silver-bearing sulfides (acanthite, argentite, polybasite), sulfosalts (argentiferous tetrahedrite of the freibergite-argentotennantite series, pyrargyrite, proustite), and $\mathrm{Ag}-\mathrm{Hg}$ amalgams as the main ore minerals. Gangue minerals consist predominantly of calcite-and to a lesser extent fluorite, dolomite, and quartz.

2. Controls on the deposit are both stratigraphic and structural as most of the highergrade orebodies are localized: (i) within the uppermost organic-rich black shale unit close to, and paralleling, the transcrustal Imiter Fault and its subsidiary satellites; and (ii) along the intersection of NW- and E-W-trending faults.

3. Mineralogy and textural relationships revealed a complex polyphase history, with at least three silver-bearing stages: (1) silver-quartz stage; (2) main silver-calcite \pm fluorite stage; and (3) late carbonate-quartz base metal sulfide stage, of which the calcite-dominant and fluorite-dominant sub-stages are economically the most characteristic.

4. Silver-rich fluids are related to the involvement of an immiscible $\mathrm{CO}_{2}$-bearing F- and $\mathrm{Cl}$-rich fluids that have evolved through magma degassing, fluid mixing, and subsequent cooling/dilution, along with interactions with the host rocks at decreasing temperatures. High concentration of fluorine and other complexing agents in this phase allowed trace elements, such as Ag and accompanying metals, to be transported in the hydrothermal solution. During the latest stage of mineralization, the hydrothermal system was invaded by meteoric fluid that entered and diluted the deep-seated magmatic brines.

5. Deposition of the silver-rich \pm base metal-rich ores could have been achieved through three possible mechanisms, including: (1) drops in pressure in response to fluid immiscibility (i.e., boiling and subsequent degassing); (2) mixing and subsequent 
cooling/dilution; and (3) fluid-rock interactions along the transcrustal Imiter Fault and associated subsidiary strike-slip faults.

Author Contributions: Conceptualization, methodology, writing—reviews and editing: M.B.; Field work, investigation, validation of data, writing —original draft preparation: M.D.; Fluid inclusion studies: G.L.; Fieldwork assistance: M.M., S.E.M. and L.M.; Funding and data curation: J.Y., A.K. and F.C. All authors have read and agreed to the published version of the manuscript.

Funding: This project gets partial funding from the European Union's Learning mobility of individuals (Project Number BE01-KA107-016242) awarded to M.B. and J.Y.

Institutional Review Board Statement: Not applicable.

Informed Consent Statement: Informed consent was obtained from all subjects involved in the study.

Data Availability Statement: Not applicable.

Acknowledgments: This research was made possible with help and support from many institutions and researchers to which/whom we would like to express our deepest gratitude. In this regard, we gratefully acknowledge scholarships of the Moroccan Ministry of Higher Education and Scientific Research and the European Union's Learning mobility program (scholarship BE01-KA107-016242) awarded to M. Bouabdellah and J. Yans that enabled the first author to complete part of this work. Our gratitude also goes to the geologists of Managem Group mining company-in particular A. Gaouzi, B. Maammar, and M. Zouhir-for supporting this project and providing access to the Imiter property, extensive sampling, and advisory assistance. Special appreciation is due to J.F. Slack who has been generous with his time by providing careful pre-editing information through several versions. We are indebted to N. Mattielli (Université Libre de Bruxelles) for enabling the strontium isotope analyses, as well as to Michel Fialin and Nicolas Rividi (CAMPARIS, Sorbonne Université) for electron microprobe analyses. We further thank the journal's anonymous referees for their helpful and constructive reviews and edits, and Rita $\mathrm{Xu}$ and Lucas Xiang for editorial handling of the manuscript which helped to greatly improve this work.

Conflicts of Interest: The authors declare no conflict of interest.

\section{References}

1. Levresse, G. Contribution à l'établissement d'un modèle génétique des gisements d'Imiter $(\mathrm{Ag}-\mathrm{Hg})$, Bou $\mathrm{Madine}(\mathrm{Pb}-\mathrm{Zn}-\mathrm{Cu}-$ Ag-Au) et Bou Azzer (Co-Ni-As-Au-Ag) dans l'Anti-Atlas marocain. Ph.D. Thesis, Institut National Polytechnique de Lorraine, Vandoeuvre-lès-Nancy, French, 2001.

2. Cheilletz, A.; Levresse, G.; Gasquet, D.; Azizi-Samir, M.; Zyadi, R.; Archibald, D.A.; Farrar, E. The giant Imiter silver deposit: Neoproterozoic epithermal mineralization in the Anti-Atlas, Morocco. Miner. Deposita 2002, 37, 772-781. [CrossRef]

3. Levresse, G.; Bouabdellah, M.; Cheilletz, A.; Gasquet, D.; Maacha, L.; Tritlla, J.; Banks, D.; Rachid, A.S.M. Degassing as the Main Ore-Forming Process at the Giant Imiter Ag-Hg Vein Deposit in the Anti-Atlas Mountains, Morocco. In Mineral Deposits of North Africa; Bouabdellah, M., Slack, J., Eds.; Springer: Berlin/Heidelberg, Germany, 2016; pp. 85-106.

4. Levresse, G.; Cheilletz, A.; Gasquet, D.; Reisberg, L.; Deloule, E.; Marty, B.; Kyser, K. Osmium, sulphur, and helium isotopic results from the giant Neoproterozoic epithermal Imiter silver deposit, Morocco: Evidence for a mantle source. Chem. Geol. 2004, 207, 59-79. [CrossRef]

5. Essarraj, S.; Boiron, M.-C.; Cathelineau, M.; Tarantola, A.; Leisen, M.; Boulvais, P.; Maacha, L. Basinal Brines at the Origin of the Imiter Ag-Hg Deposit (Anti-Atlas, Morocco): Evidence from LA-ICP-MS Data on Fluid Inclusions, Halogen Signatures, and Stable Isotopes (H, C, O). Econ. Geol. 2016, 111, 1753-1781. [CrossRef]

6. Bouabdellah, M.; Slack, J.F. Mineral Deposits of North Africa; Bouabdellah, M., Slack, J.F., Eds.; Springer: Berlin/Heidelberg, Germany, 2016; p. 594.

7. Gasquet, D.; Ennih, N.; Liégeois, J.-P.; Soulaimani, A.; Michard, A. The Pan-African Belt. In Continental Evolution: The Geology of Morocco: Structure, Stratigraphy, and Tectonics of the Africa-Atlantic-Mediterranean Triple Junction; Michard, A., Saddiqi, O., Chalouan, A., Lamotte, D.F.d., Eds.; Springer: Berlin/Heidelberg, Germany, 2008; pp. 33-64.

8. Gasquet, D.; Levresse, G.; Cheilletz, A.; Azizi-Samir, M.R.; Mouttaqi, A. Contribution to a geodynamic reconstruction of the Anti-Atlas (Morocco) during Pan-African times with the emphasis on inversion tectonics and metallogenic activity at the Precambrian-Cambrian transition. Precambrian Res. 2005, 140, 157-182. [CrossRef]

9. Thomas, R.J.; Fekkak, A.; Ennih, N.; Errami, E.; Loughlin, S.C.; Gresse, P.G.; Chevallier, L.P.; Liégeois, J.P. A new lithostratigraphic framework for the Anti-Atlas Orogen, Morocco. J. Afr. Earth Sci. 2004, 39, 217-226. [CrossRef]

10. Walsh, G.J.; Benziane, F.; Aleinikoff, J.N.; Harrison, R.W.; Yazidi, A.; Burton, W.C.; Quick, J.E.; Saadane, A. Neoproterozoic tectonic evolution of the Jebel Saghro and Bou Azzer-El Graara inliers, eastern and central Anti-Atlas, Morocco. Precambrian Res. 2012, 216-219, 23-62. [CrossRef] 
11. Michard, A.; Soulaimani, A.; Ouanaimi, H.; Raddi, Y.; Aït Brahim, L.; Rjimati, E.-C.; Baidder, L.; Saddiqi, O. Saghro Group in the Ougnat Massif (Morocco), an evidence for a continuous Cadomian basin along the northern West African Craton. Comptes Rendus Geosci. 2017, 349, 81-90. [CrossRef]

12. Errami, E.; Linnemann, U.; Hofmann, M.; Gärtner, A.; Zieger, J.; Gärtner, J.; Mende, K.; El Kabouri, J.; Gasquet, D.; Ennih, N. From Pan-African Transpression to Cadomian Transtension at the West African Margin: New U-Pb zircon Ages from the Eastern Saghro Inlier (Anti-Atlas, Morocco). Geol. Soc. Lond. Spec. Publ. 2021, 503, 209-233.

13. Liégeois, J.; Fekkak, A.; Bruguier, O.; Errami, E.; Ennih, N. The Lower Ediacaran (630-610 Ma) Saghro group: An orogenic transpressive basin development during the early metacratonic evolution of the Anti-Atlas (Morocco). In Proceedings of the IGCP485 4th Meeting, Algiers, Algeria, 2 September 2006.

14. Abati, J.; Aghzer, A.M.; Gerdes, A.; Ennih, N. Detrital zircon ages of Neoproterozoic sequences of the Moroccan Anti-Atlas belt. Precambrian Res. 2010, 181, 115-128. [CrossRef]

15. Hefferan, K.; Soulaimani, A.; Samson, S.D.; Admou, H.; Inglis, J.; Saquaque, A.; Latifa, C.; Heywood, N. A reconsideration of Pan African orogenic cycle in the Anti-Atlas Mountains, Morocco. J. Afr. Earth Sci. 2014, 98, 34-46. [CrossRef]

16. Linnemann, U.; Gerdes, A.; Hofmann, M.; Marko, L. The Cadomian Orogen: Neoproterozoic to Early Cambrian crustal growth and orogenic zoning along the periphery of the West African Craton-Constraints from U-Pb zircon ages and Hf isotopes (Schwarzburg Antiform, Germany). Precambrian Res. 2014, 244, 236-278. [CrossRef]

17. Baidada, B.; Cousens, B.; Alansari, A.; Soulaimani, A.; Barbey, P.; Ilmen, S.; Ikenne, M. Geochemistry and Sm-Nd isotopic composition of the Imiter Pan-African granitoids (Saghro massif, eastern Anti-Atlas, Morocco): Geotectonic implications. J. Afr. Earth Sci. 2017, 127, 99-112. [CrossRef]

18. El Boukhari, A.; Musumeci, G.; Algouti, A.B.; Cerrina Feroni, A.; Ghiselli, F.; Ottria, G.; Ouanaimi, H.; Pertusati, P.; Taj Eddine, K. Notice Explicative de la Carte Géologique du Maroc au 1/50.000, feuille Imi n'Ouzrou; Royaume Du Maroc Ministère De L'énergie Et Des Mines: Rabat, Morocco, 2007.

19. Malusà, M.G.; Polino, R.; Feroni, A.C.; Ellero, A.; Ottria, G.; Baidder, L.; Musumeci, G. Post-Variscan tectonics in eastern anti-atlas (Morocco). Terra Nova 2007, 19, 481-489. [CrossRef]

20. Massironi, M.; Moratti, G.; Algouti, A.H.; Benvenuti, M.; Dal Piaz, G.V.; Eddebbi, A.; El Boukhari, A.; Laftouhi, N.; Ouanaimi, H.; Schiavo, A.; et al. Carte géologique du Maroc au 1/50 000, feuille Boumalne. Notes Mém. Ser. Géol. Maroc 2007, 521, 1-80.

21. Ouguir, H.; Macaudière, J.; Dagallier, G. Le protérozoïque supérieur d'imiter, Saghro oriental, Maroc: Un contexte géodynamique d'arrière-arc. J. Afr. Earth Sci. 1996, 22, 173-189. [CrossRef]

22. Tuduri, J. Formation process, geometrical and chronological relationships of Au-Ag mineralization formed within Neoproterozoic volcanic context (Jbel Saghro, Anti-Atlas, Morocco). Consequences on the interactions between deformation, magmatism, volcanism and hydrothermalism. Ph.D. Thesis, Université d'Orléans, Orléans, France, 2005.

23. Soulaimani, A.; Bouabdelli, M.; Piqué, A. L'extension continentale au Néo-Protérozoïque supérieur-Cambrien inférieur dans l'Anti-Atlas (Maroc); Bulletin de la Société Géologique de France: Paris, France, 2003.

24. Benssaou, M.; Hamoumi, N. The Lower-Cambrian western Anti-Atlasic graben: Tectonic control of palaeogeography and sequential organisation. Comptes Rendus Géosci. 2003, 335, 297-305. [CrossRef]

25. Buggisch, W.; Siegert, R. Paleogeography and facies of the 'grès terminaux' (uppermost Lower Cambrian, Anti-Atlas/Morocco). In The Atlas System of Morocco; Springer: Berlin/Heidelberg, Germany, 1988; pp. 107-121.

26. Piqué, A.; Laville, E.; Chotin, P.; Chorowicz, J.; Rakotondraompiana, S.; Thouin, C. L'extension à Madagascar du Néogène à l'Actuel: Arguments structuraux et géophysiques. J. Afr. Earth Sci. 1999, 28, 975-983. [CrossRef]

27. Soulaimani, A.; Michard, A.; Ouanaimi, H.; Baidder, L.; Raddi, Y.; Saddiqi, O.; Rjimati, E. Late Ediacaran-Cambrian structures and their reactivation during the Variscan and Alpine cycles in the Anti-Atlas (Morocco). J. Afr. Earth Sci. 2014, 98, 94-112. [CrossRef]

28. Baidada, B.; Ikenne, M.; Barbey, P.; Soulaimani, A.; Cousens, B.; Haissen, F.; Ilmen, S.; Alansari, A. SHRIMP U-Pb zircon geochronology of the granitoids of the Imiter Inlier: Constraints on the Pan-African events in the Saghro massif, Anti-Atlas (Morocco). J. Afr. Earth Sci. 2019, 150, 799-810. [CrossRef]

29. De Wall, H.; Kober, B.; Errami, E.; Ennih, N.; Greiling, R.O. Age de mise en place et contexte géologique des granitoïdes de la boutonnière d'Imiter (Saghro oriental, Anti-Atlas, Maroc): 2ème Colloque International. Marrakech Magmatisme Métamorphisme et Minéralisations Associées 2001, 10, 19.

30. Tuduri, J.; Chauvet, A.; Barbanson, L.; Labriki, M.; Dubois, M.; Trapy, P.-H.; Lahfid, A.; Poujol, M.; Melleton, J.; Badra, L.; et al. Structural control, magmatic-hydrothermal evolution and formation of hornfels-hosted, intrusion-related gold deposits: Insight from the Thaghassa deposit in Eastern Anti-Atlas, Morocco. Ore Geol. Rev. 2018, 97, 171-198. [CrossRef]

31. Bajja, A. Volcanisme syn à post orogénique du néoprotérozoïque de l'Anti-Atlas: Implications pétrogénétiques et géodynamiques. Ph.D. Thesis, Universite Chouaib Doukkali, El Jadida, Morocco, 1998.

32. El Baghdadi, M.; El Boukhari, A.; Jouider, A.; Benyoucef, A.; Nadem, S. Calc-alkaline arc I-type granitoid associated with S-type granite in the Pan-African belt of eastern Anti-Atlas (Saghro and Ougnat, South Morocco). Gondwana Res. 2003, 6, 557-572. [CrossRef]

33. Pouclet, A.; Aarab, A.; Fekkak, A.; Benharref, M. Geodynamic evolution of the northwestern Paleo-Gondwanan margin in the Moroccan Atlas at the Precambrian-Cambrian boundary. Spec. Pap.-Geol. Soc. Am. 2007, 423, 27-60. 
34. Soulaimani, A.; Ouanaimi, H.; Saddiqi, O.; Baidder, L.; Michard, A. The anti-atlas pan-african belt (Morocco): Overview and pending questions. Comptes Rendus Geosci. 2018, 350, 279-288. [CrossRef]

35. Thomas, R.J.; Chevallier, L.P.; Gresse, P.G.; Harmer, R.E.; Eglington, B.M.; Armstrong, R.A.; de Beer, C.H.; Martini, J.E.J.; de Kock, G.S.; Macey, P.H.; et al. Precambrian evolution of the Sirwa Window, Anti-Atlas Orogen, Morocco. Precambrian Res. 2002, 118, 1-57. [CrossRef]

36. Toummite, A.; Liegeois, J.P.; Gasquet, D.; Bruguier, O.; Beraaouz, E.H.; Ikenne, M. Field, geochemistry and Sr-Nd isotopes of the Pan-African granitoids from the Tifnoute Valley (Sirwa, Anti-Atlas, Morocco): A post-collisional event in a metacratonic setting. Mineral. Petrol 2013, 107, 739-763. [CrossRef]

37. Michard, A.; Yazidi, A.; Benziane, F.; Hollard, H.; Willefert, S. Foreland thrusts and olistromes on the pre-Sahara margin of the Variscan orogen, Morocco. Geology 1982, 10, 253-256. [CrossRef]

38. Hoepffner, C.; Soulaimani, A.; Piqué, A. The Moroccan Hercynides. J. Afr. Earth Sci. 2005, 43, 144-165. [CrossRef]

39. Burkhard, M.; Caritg, S.; Helg, U.; Robert-Charrue, C.; Soulaimani, A. Tectonics of the Anti-Atlas of Morocco. Comptes Rendus Geosci. 2006, 338, 11-24. [CrossRef]

40. Marzoli, A.; Jourdan, F.; Puffer, J.H.; Cuppone, T.; Tanner, L.H.; Weems, R.E.; Bertrand, H.; Cirilli, S.; Bellieni, G.; De Min, A. Timing and duration of the Central Atlantic magmatic province in the Newark and Culpeper basins, eastern USA. Lithos 2011, 122, 175-188. [CrossRef]

41. Bourdier, J.-L.; Hejja, Y.; Gaouzi, A.; El Basbas, A.; Ennaciri, A.; Zakir, A.; Baidder, L.; Maacha, L. Lithostratigraphie des formations édiacariennes NP3 de la boutonnière d'Imiter (Saghro, Anti-Atlas): Cycles volcano-plutoniques et implications sur l'âge de la faille d'Imiter. In Proceedings of the 11ème Colloque «Magmatisme, Métamorphisme et Minéralisations Associées» 3MA11El Jadida, El Jadida, Morocco, 23-24 April 2019; pp. 7-9.

42. Hejja, Y.; Baidder, L.; Ibouh, H.; Bba, A.N.; Soulaimani, A.; Gaouzi, A.; Maacha, L. Fractures distribution and basement-cover interaction in a polytectonic domain: A case study from the Saghro Massif (Eastern Anti-Atlas, Morocco). J. Afr. Earth Sci. 2020, 162, 103694. [CrossRef]

43. Tuduri, J.; Chauvet, A.; Ennaciri, A.; Barbanson, L. Modèle de formation du gisement d'argent d'Imiter (Anti-Atlas oriental, Maroc). Nouveaux apports de l'analyse structurale et minéralogique. Model of formation of the Imiter silver deposit (eastern Anti-Atlas, Morocco). New structural and mineralogical constraints. Comptes Rendus Geosci. 2006, 338, $253-261$.

44. Leistel, J.-M.; Qadrouci, A. Le gisement argentifère d'Imiter (Protérozöque supérieur de l'Anti-Atlas, Maroc). Contrôles des minéralisations, hypothèse génétique et perspectives pour l'exploration. Chronique de la Recherche Minière 1991, 502, 5-22.

45. Gasquet, D.; Bouloton, J. Les filons de microdiorite des Jebilet centrales (Meseta marocaine): Pré-rifting permien. Abstract Réunion extraordinaire de la Société Géologique de France, Marrakech, Morocco 1995, 55. Available online: https: / / core.ac.uk/download/pdf/ 46813017.pdf (accessed on 1 January 2021).

46. Youbi, N.; Bellon, H.; Marzin, A.; Piqué, A.; Cotten, J.; Cabanis, B. Du cycle orogénique hercynien au pré-rifting de l’Atlantique central au Maroc occidental: Les microdiorites des Jbilet sont-elles des marqueurs magmatiques de ce passage? Comptes Rendus de l'Académie des Sciences-Series IIA-Earth and Planetary Science 2001, 333, 295-302. [CrossRef]

47. Dostal, J.; Keppie, J.D.; Hamilton, M.A.; Aarab, E.M.; Lefort, J.P.; Murphy, J.B. Crustal xenoliths in Triassic lamprophyre dykes in western Morocco: Tectonic implications for the Rheic Ocean suture. Geol. Mag. 2005, 142, 159-172. [CrossRef]

48. Bouloton, J.; Gasquet, D.; Pin, C. Petrogenesis of the Early-Triassic quartz-monzodiorite dykes from Central Jebilet (Moroccan Meseta): Trace element and Nd-Sr isotope constraints on magma sources, and inferences on their geodynamic context. J. Afr. Earth Sci. 2019, 149, 451-464. [CrossRef]

49. Ikenne, M.; Ennaciri, A.; Ouguir, H.; Cousens, B.; Ziyadi, R.; Mouhagir, M.; El-Gaouzi, A. Geochemical signature and geodynamic significance of an $\mathrm{Ag}-\mathrm{Hg}$ mineralized dyke swarm in the neoproterozoic inlier of Imiter-Anti-Atlas (Morocco). Ofioliti 2007, $32,109-118$.

50. Belkacim, S.; Gasquet, D.; Liégeois, J.-P.; Arai, S.; Gahlan, H.A.; Ahmed, H.; Ishida, Y.; Ikenne, M. The Ediacaran volcanic rocks and associated mafic dykes of the Ouarzazate Group (Anti-Atlas, Morocco): Clinopyroxene composition, whole-rock geochemistry and Sr-Nd isotopes constraints from the Ouzellarh-Siroua salient (Tifnoute valley). J. Afr. Earth Sci. 2017, 127, 113-135. [CrossRef]

51. Bouabdellah, M.; Slack, J.F. Geologic and Metallogenic Framework of North Africa. In Mineral Deposits of North Africa, Bouabdellah, M., Slack, J.F., Eds.; Springer International Publishing: Cham, Germany, 2016; pp. 3-81.

52. Margoum, D.; Bouabdellah, M.; Klügel, A.; Banks, D.A.; Castorina, F.; Cuney, M.; Jébrak, M.; Bozkaya, G. Pangea rifting and onward pre-Central Atlantic opening as the main ore-forming processes for the genesis of the Aouli REE-rich fluorite-barite vein system, upper Moulouya district, Morocco. J. Afr. Earth Sci. 2015, 108, 22-39. [CrossRef]

53. Coplen, T.B. Reporting of stable carbon, hydrogen, and oxygen isotopic abundances. Ref. Intercomp. Mater. Stable Isot. Light Elem. IAEA-Tecdoc 1995, 825, 31-34. [CrossRef]

54. Snoeck, C.; Lee-Thorp, J.; Schulting, R.; de Jong, J.; Debouge, W.; Mattielli, N. Calcined bone provides a reliable substrate for strontium isotope ratios as shown by an enrichment experiment. Rapid Commun. Mass Spectrom. 2015, 29, 107-114. [CrossRef]

55. Weis, D.; Kieffer, B.; Maerschalk, C.; Barling, J.; De Jong, J.; Williams, G.A.; Hanano, D.; Pretorius, W.; Mattielli, N.; Scoates, J.S. High-precision isotopic characterization of USGS reference materials by TIMS and MC-ICP-MS. Geochem. Geophys. 2006, 7. [CrossRef]

56. Winchester, J.A.; Floyd, P.A. Geochemical discrimination of different magma series and their differentiation products using immobile elements. Chem. Geol. 1977, 20, 325-343. [CrossRef] 
57. Pearce, J.A. Geochemical fingerprinting of oceanic basalts with applications to ophiolite classification and the search for Archean oceanic crust. Lithos 2008, 100, 14-48. [CrossRef]

58. Pearce, J.A. A user's guide to basalt discrimination diagrams. Trace Elem. Geochem. Volcan. Rocks 1996, $12,113$.

59. Maniar, P.D.; Piccoli, P.M. Tectonic discrimination of granitoids. Geol. Soc. Am. Bull. 1989, 101, 635-643. [CrossRef]

60. Peccerillo, A.; Taylor, S.R. Geochemistry of eocene calc-alkaline volcanic rocks from the Kastamonu area, Northern Turkey. Contrib. Mineral. Petrol. 1976, 58, 63-81. [CrossRef]

61. McDonough, W.F.; Sun, S.-S. The composition of the Earth. Chem. Geol. 1995, 120, 223-253. [CrossRef]

62. Roedder, E. Volume 12: Fluid Inclusions; De Gruyter: Berlin, Gamany, 1984; p. 646.

63. Steele-MacInnis, M.; Han, L.; Lowell, R.P.; Rimstidt, J.D.; Bodnar, R.J. The role of fluid phase immiscibility in quartz dissolution and precipitation in sub-seafloor hydrothermal systems. Earth Planet. Sci. Lett. 2012, 321, 139-151. [CrossRef]

64. Oakes, J. Multiplying Inequalities: The Effects of Race, Social Class, and Tracking on Opportunities to Learn Mathematics and Science; ERIC: Santa Monica, CA, USA, 1990.

65. Jenkyns, H.C.; Jones, C.E.; GrÖcke, D.R.; Hesselbo, S.P.; Parkinson, D.N. Chemostratigraphy of the Jurassic System: Applications, limitations and implications for palaeoceanography. J. Geol. Soc. 2002, 159, 351-378. [CrossRef]

66. Veizer, J.; Ala, D.; Azmy, K.; Bruckschen, P.; Buhl, D.; Bruhn, F.; Carden, G.A.F.; Diener, A.; Ebneth, S.; Godderis, Y.; et al. ${ }^{87} \mathrm{Sr} /{ }^{86} \mathrm{Sr}$, $\delta^{13} \mathrm{C}$ and $\delta^{18} \mathrm{O}$ evolution of Phanerozoic seawater. Chem. Geol. 1999, 161, 59-88. [CrossRef]

67. Zheng, Y.-F. Calculation of oxygen isotope fractionation in hydroxyl-bearing silicates. Earth Planet. Sci. Lett. 1993, 120, 247-263. [CrossRef]

68. Zheng, Y.-F. Oxygen isotope fractionation in carbonate and sulfate minerals. Geochem. J. 1999, 33, 109-126. [CrossRef]

69. Jacobsen, S.B.; Kaufman, A.J. The Sr, C and O isotopic evolution of Neoproterozoic seawater. Chem. Geol. 1999, 161, 37-57. [CrossRef]

70. Taylor Jr, H.P.; Frechen, J.; Degens, E.T. Oxygen and carbon isotope studies of carbonatites from the Laacher See District, West Germany and the Alnö District, Sweden. Geochim. Cosmochim. Acta 1967, 31, 407-430. [CrossRef]

71. Keller, J.; Hoefs, J. Stable isotope characteristics of recent natrocarbonatites from Oldoinyo Lengai. In Carbonatite Volcanism; Springer: Berlin/Heidelberg, Germany, 1995; pp. 113-123.

72. Lindgren, W. Mineral Deposits; McGraw-Hill Book Company, Incorporated: New York, NY, USA, 1933.

73. Essarraj, S.; Boiron, M.-C.; Cathelineau, M.; Peiffert, C. Evaporitic brines and copper-sulphide ore genesis at Jbel Haïmer (Central Jebilet, Morocco). Ore Geol. Rev. 2020, 129, 103920. [CrossRef]

74. Jochum, K.P.; Seufert, H.M.; Spettel, B.; Palme, H. The solar-system abundances of Nb, Ta, and Y, and the relative abundances of refractory lithophile elements in differentiated planetary bodies. Geochim. Cosmochim. Acta 1986, 50, 1173-1183. [CrossRef]

75. Bau, M.; Koschinsky, A.; Dulski, P.; Hein, J.R. Comparison of the partitioning behaviours of yttrium, rare earth elements, and titanium between hydrogenetic marine ferromanganese crusts and seawater. Geochim. Cosmochim. Acta 1996, 60, 1709-1725. [CrossRef]

76. Chakhmouradian, A.R.; Reguir, E.P.; Couëslan, C.; Yang, P. Calcite and dolomite in intrusive carbonatites. II. Trace-element variations. Mineral. Petrol. 2016, 110, 361-377. [CrossRef]

77. Chakhmouradian, A.R.; Reguir, E.P.; Kamenetsky, V.S.; Sharygin, V.V.; Golovin, A.V. Trace-element partitioning in perovskite: Implications for the geochemistry of kimberlites and other mantle-derived undersaturated rocks. Chem. Geol. 2013, 353, 112-131. [CrossRef]

78. Giggenbach, W. Isotopic shifts in waters from geothermal and volcanic systems along convergent plate boundaries and their origin. Earth Planet. Sci. Lett. 1992, 113, 495-510. [CrossRef]

79. Taylor, H.P. The application of oxygen and hydrogen isotope studies to problems of hydrothermal alteration and ore deposition. Econ. Geol. 1974, 69, 843-883. [CrossRef]

80. Balabin, A.I.; Sack, R.O. Thermodynamics of (Zn, Fe) S sphalerite. A CVM approach with large basis clusters. Mineral. Mag. 2000, 64, 923-943. [CrossRef]

81. Zhai, D.; Williams-Jones, A.E.; Liu, J.; Selby, D.; Voudouris, P.C.; Tombros, S.; Li, K.; Li, P.; Sun, H. The Genesis of the Giant Shuangjianzishan Epithermal Ag-Pb-Zn Deposit, Inner Mongolia, Northeastern China. Econ. Geol. 2020, 115, 101-128. [CrossRef]

82. Sack, R.O.; Fredericks, R.; Hardy, L.S.; Ebel, D.S. Origin of high-Ag fahlores from the Galena mine, Wallace, Idaho, USA. Am. Mineral. 2005, 90, 1000-1007. [CrossRef]

83. Deines, P. The carbon isotope geochemistry of mantle xenoliths. Earth-Sci. Rev. 2002, 58, 247-278. [CrossRef]

84. Hoefs, J. Variations of stable isotope ratios in nature. In Stable Isotope Geochemistry; Springer: Berlin/Heidelberg, Germany, 2009; pp. 93-227.

85. Keppler, H.; Wyllie, P.J. Role of fluids in transport and fractionation of uranium and thorium in magmatic processes. Nature 1990, 348, 531-533. [CrossRef]

86. Keppler, H.; Wyllie, P.J. Partitioning of $\mathrm{Cu}, \mathrm{Sn}, \mathrm{Mo}, \mathrm{W}, \mathrm{U}$, and Th between melt and aqueous fluid in the systems haplogranite$\mathrm{H}_{2} \mathrm{O}-\mathrm{HCl}$ and haplogranite- $\mathrm{H}_{2} \mathrm{O}-\mathrm{HF}$. Contrib. Mineral. Petrol. 1991, 109, 139-150. [CrossRef]

87. London, D.; Hervig, R.L.; Morgan, G.B. Melt-vapor solubilities and elemental partitioning in peraluminous granite-pegmatite systems: Experimental results with Macusani glass at $200 \mathrm{MPa}$. Contrib. Mineral. Petrol. 1988, 99, 360-373. [CrossRef]

88. Webster, J.D.; Holloway, J.R.; Hervig, R.L. Partitioning of lithophile trace elements between $\mathrm{H}_{2} \mathrm{O}$ and $\mathrm{H}_{2} \mathrm{O}+\mathrm{CO}_{2}$ fluids and topaz rhyolite melt. Econ. Geol. 1989, 84, 116-134. [CrossRef] 
89. Gagnon, J.E.; Samson, I.M.; Fryer, B.J.; Williams-Jones, A.E. Compositional heterogeneity in fluorite and the genesis of fluorite deposits: Insights from LA-ICP-MS analysis. Canad. Mineral. 2003, 41, 365-382. [CrossRef]

90. Gabitov, R.I.; Sadekov, A.; Migdisov, A. REE incorporation into calcite individual crystals as one time spike addition. Minerals 2017, 7, 204. [CrossRef]

91. Möller, P.; Bau, M.; Dulski, P.; Lüders, V. REE and yttrium fractionation in fluorite and their bearing on fluorite formation. In Proceedings of the 9th Quadrennial IAGOD Symposium, Beijing, China, 12-18 August 1994; pp. 575-592.

92. Borisenko, A.; Borovikov, A.A.; Pavlova, G.G.; Kalinin, Y.A.; Nevolko, P.A.; Gushchina, L.V.; Lebedev, V.I.; Maacha, L.; Kostin, A.V. Formation conditions of Hg-silver deposition at the Imiter deposit (Anti-Atlas, Morocco). In Mineral Depostits for a High-Tech World, Proceedings of the 12th SGA Biennial Meeting 2013, Uppsala, Sweden, 12-15 August 2013; Jonsson, E., Ed.; Elanders Sverige AB: Uppsala, Sweden, 2013; Volume 3, pp. 1243-1246. 